\title{
Ozone photochemistry in an oil and natural gas extraction region during winter: simulations of a snow-free season in the Uintah Basin, Utah
}

\author{
P. M. Edwards ${ }^{1,2}$, C. J. Young ${ }^{1, *}$, K. Aikin ${ }^{1,2}$, J. deGouw ${ }^{1,2}$, W. P. Dubé ${ }^{1,2}$, F. Geiger ${ }^{3}$, J. Gilman ${ }^{1,2}$, D. Helmig ${ }^{4}$, \\ J. S. Holloway ${ }^{1,2}$, J. Kercher ${ }^{5}$, B. Lerner ${ }^{1,2}$, R. Martin $^{6}$, R. McLaren ${ }^{7}$, D. D. Parrish ${ }^{1}$, J. Peischl ${ }^{1,2}$, J. M. Roberts ${ }^{1}$, \\ T. B. Ryerson ${ }^{1}$, J. Thornton ${ }^{8}$, C. Warneke ${ }^{1,2}$, E. J. Williams ${ }^{1}$, and S. S. Brown ${ }^{1}$ \\ ${ }^{1}$ NOAA Earth System Research Laboratory, R/CSD7, 325 Broadway, Boulder, CO, USA \\ ${ }^{2}$ Cooperative Institute for Research in Environmental Sciences, University of Colorado, Boulder, CO, USA \\ ${ }^{3}$ Karlsruher Institute für Technologie, IMK-ASF, Karlsruhe, Germany \\ ${ }^{4}$ Institute of Arctic and Alpine Research, University of Colorado Boulder, Boulder, Colorado, CO, USA \\ ${ }^{5}$ Chemistry Department, Hiram College, Hiram, Ohio, USA \\ ${ }^{6}$ Civil and Environmental Engineering Department, Utah State University, UT, USA \\ ${ }^{7}$ Centre for Atmospheric Chemistry, York University, Toronto, ON, Canada \\ ${ }^{8}$ Department of Atmospheric Sciences, University of Washington, Seattle, USA \\ *now at: Department of Chemistry, Memorial University of Newfoundland, St. John's, NL Canada
}

Correspondence to: P. M. Edwards (peter.m.edwards@noaa.gov)

Received: 5 March 2013 - Published in Atmos. Chem. Phys. Discuss.: 20 March 2013

Revised: 24 July 2013 - Accepted: 1 August 2013 - Published: 9 September 2013

\begin{abstract}
The Uintah Basin in northeastern Utah, a region of intense oil and gas extraction, experienced ozone $\left(\mathrm{O}_{3}\right)$ concentrations above levels harmful to human health for multiple days during the winters of 2009-2010 and 2010-2011. These wintertime $\mathrm{O}_{3}$ pollution episodes occur during cold, stable periods when the ground is snow-covered, and have been linked to emissions from the oil and gas extraction process. The Uintah Basin Winter Ozone Study (UBWOS) was a field intensive in early 2012, whose goal was to address current uncertainties in the chemical and physical processes that drive wintertime $\mathrm{O}_{3}$ production in regions of oil and gas development. Although elevated $\mathrm{O}_{3}$ concentrations were not observed during the winter of 2011-2012, the comprehensive set of observations tests our understanding of $\mathrm{O}_{3}$ photochemistry in this unusual emissions environment. A box model, constrained to the observations and using the nearexplicit Master Chemical Mechanism (MCM) v3.2 chemistry scheme, has been used to investigate the sensitivities of $\mathrm{O}_{3}$ production during UBWOS 2012. Simulations identify the $\mathrm{O}_{3}$ production photochemistry to be highly radical limited (with a radical production rate significantly smaller
\end{abstract}

than the $\mathrm{NO}_{\mathrm{x}}$ emission rate). Production of $\mathrm{OH}$ from $\mathrm{O}_{3}$ photolysis (through reaction of $\mathrm{O}\left({ }^{1} \mathrm{D}\right)$ with water vapor) contributed only $170 \mathrm{pptv}^{-1} \mathrm{day}^{-1}, 8 \%$ of the total primary radical source on average (primary radicals being those produced from non-radical precursors). Other radical sources, including the photolysis of formaldehyde ( $\mathrm{HCHO}, 52 \%)$, nitrous acid (HONO, $26 \%)$, and nitryl chloride $\left(\mathrm{ClNO}_{2}, 13 \%\right)$ were larger. $\mathrm{O}_{3}$ production was also found to be highly sensitive to aromatic volatile organic compound (VOC) concentrations, due to radical amplification reactions in the oxidation scheme of these species. Radical production was shown to be small in comparison to the emissions of nitrogen oxides $\left(\mathrm{NO}_{\mathrm{x}}\right)$, such that $\mathrm{NO}_{\mathrm{x}}$ acted as the primary radical sink. Consequently, the system was highly VOC sensitive, despite the much larger mixing ratio of total non-methane hydrocarbons ( $230 \mathrm{ppbv}$ (2080 ppbC), 6 week average) relative to $\mathrm{NO}_{\mathrm{x}}$ (5.6 ppbv average). However, the importance of radical sources which are themselves derived from $\mathrm{NO}_{\mathrm{x}}$ emissions and chemistry, such as $\mathrm{ClNO}_{2}$ and $\mathrm{HONO}$, make the response of the system to changes in $\mathrm{NO}_{\mathrm{x}}$ emissions uncertain. Model simulations attempting to reproduce conditions 
expected during snow-covered cold-pool conditions show a significant increase in $\mathrm{O}_{3}$ production, although calculated concentrations do not achieve the highest seen during the 2010-2011 O $\mathrm{O}_{3}$ pollution events in the Uintah Basin. These box model simulations provide useful insight into the chemistry controlling winter $\mathrm{O}_{3}$ production in regions of oil and gas extraction.

\section{Introduction}

Tropospheric ozone $\left(\mathrm{O}_{3}\right)$ is an air pollutant with severe respiratory health effects (Finlayson-Pitts and Pitts, 1997; Brown et al., 2008; Jerrett et al., 2009). In the United States $\mathrm{O}_{3}$ concentrations are monitored and controlled by the US Environmental Protection Agency (EPA, 1986). Although $\mathrm{O}_{3}$ pollution is normally associated with summertime photochemical smog in urban areas, during recent years, wintertime $\mathrm{O}_{3}$ pollution episodes have been observed in remote regions where oil and gas extraction has seen rapid growth (Schnell et al., 2009). Many aspects of the chemistry responsible for these high wintertime $\mathrm{O}_{3}$ concentrations are uncertain, in particular the role of emissions associated with the oil and gas extraction process. Natural gas extraction in the US has increased rapidly since 2005 (EIA), with this growth forecast to continue. Therefore, the impacts of emissions from this sector on local and regional air quality must be understood.

Unlike many other tropospheric pollutants, $\mathrm{O}_{3}$ is not emitted directly. The only known sources of tropospheric $\mathrm{O}_{3}$ are entrainment of $\mathrm{O}_{3}$ rich air from the stratosphere and in situ photolysis of nitrogen dioxide $\left(\mathrm{NO}_{2}\right)$ and subsequent reaction of the $\mathrm{O}\left({ }^{3} \mathrm{P}\right)$ with molecular oxygen (Reaction $\mathrm{R} 1$ ) (Crutzen, 1994; Roelofs and Lelieveld, 1995). The nitric oxide (NO) generated by Reaction (R1) can subsequently react with $\mathrm{O}_{3}$ to regenerate $\mathrm{NO}_{2}$ (Reaction $\mathrm{R} 2$ ), and therefore Reactions (R1)-(R2) constitute a cycle that creates and destroys $\mathrm{O}_{3}$ but is overall null in $\mathrm{O}_{\mathrm{x}}\left(\mathrm{O}_{\mathrm{x}}=\mathrm{NO}_{2}+\mathrm{O}_{3}\right)$.

$\mathrm{NO}_{2} \stackrel{h v}{\longrightarrow} \mathrm{NO}+\mathrm{O}\left({ }^{3} \mathrm{P}\right)$

$\mathrm{O}\left({ }^{3} \mathrm{P}\right)+\mathrm{O}_{2}+\mathrm{M} \longrightarrow \mathrm{O}_{3}+\mathrm{M}$

$\mathrm{O}_{3}+\mathrm{NO} \longrightarrow \mathrm{NO}_{2}+\mathrm{O}_{2}$

This null $\mathrm{O}_{\mathrm{x}}$ cycle is disturbed by reactions that convert NO into $\mathrm{NO}_{2}$ but do not destroy $\mathrm{O}_{3}$, thus resulting in a net increase in $\mathrm{O}_{3}$ concentration. Such $\mathrm{NO}$ to $\mathrm{NO}_{2}$ conversions occur during the radical catalyzed oxidation of hydrocarbons and carbon monoxide (CO) (Reactions (R3)-(R8), where R represents a hydrocarbon species), and lead to tropospheric $\mathrm{O}_{3}$ production.

$\mathrm{CO}+\mathrm{OH} \longrightarrow \mathrm{CO}_{2}+\mathrm{H}$

$$
\begin{aligned}
& \mathrm{H}+\mathrm{O}_{2}+\mathrm{M} \longrightarrow \mathrm{HO}_{2}+\mathrm{M} \\
& \mathrm{RH}+\mathrm{OH} \longrightarrow \mathrm{R}^{\bullet}+\mathrm{H}_{2} \mathrm{O} \\
& \mathrm{R}^{\bullet}+\mathrm{O}_{2}+\mathrm{M} \longrightarrow \mathrm{RO}_{2}^{\bullet}+\mathrm{M} \\
& \mathrm{RO}_{2}^{\bullet}+\mathrm{NO} \longrightarrow \mathrm{RO}^{\bullet}+\mathrm{NO}_{2} \\
& \mathrm{RO}^{\bullet}+\mathrm{O}_{2} \longrightarrow \text { carbonyl }+\mathrm{HO}_{2}^{\bullet} \\
& \mathrm{HO}_{2}^{\bullet}+\mathrm{NO} \longrightarrow \mathrm{NO}_{2}+\mathrm{OH}
\end{aligned}
$$

Hydrocarbons and $\mathrm{NO}_{\mathrm{x}}\left(\mathrm{NO}_{\mathrm{x}}=\mathrm{NO}+\mathrm{NO}_{2}\right)$ thus serve as $\mathrm{O}_{3}$ precursors, with the potential for the production of two $\mathrm{O}_{3}$ molecules from each cycle of Reactions (R4)-(R8). As the hydroxyl radical $(\mathrm{OH})$ responsible for initiating the hydrocarbon oxidation (Reaction R4) is regenerated (Reaction $\mathrm{R} 8$ ), the number of $\mathrm{NO}$ to $\mathrm{NO}_{2}$ conversions that occur is determined by how many oxidation cycles an $\mathrm{OH}$ radical catalyzes before it is irreversibly lost. This radical propagation efficiency is often referred to as the $\mathrm{OH}$ chain length, with a longer chain length resulting from more oxidative cycles per $\mathrm{OH}$ radical produced, and thus more $\mathrm{O}_{3}$ produced (Tonnesen and Dennis, 2000; Thornton et al., 2002). $\mathrm{O}_{3}$ production is therefore dependent on the relative concentrations of $\mathrm{NO}_{\mathrm{x}}$, hydrocarbons, and radicals, as well as the efficiency of the catalytic oxidation cycles. The dependence of $\mathrm{O}_{3}$ production on its precursor concentrations is, however, highly non-linear as the reaction of radicals with $\mathrm{NO}_{\mathrm{x}}$ provides an effective loss mechanism for both species (e.g., Reactions R9-10).

$\mathrm{OH}+\mathrm{NO}_{2} \longrightarrow \mathrm{HNO}_{3}$

$\mathrm{RO}_{2}^{\bullet}+\mathrm{NO} \longrightarrow$ organic nitrate

$\mathrm{O}_{3}$ production efficiency is also sensitive to primary radical production, as it is radicals that drive the oxidation cycles resulting in $\mathrm{O}_{3}$ formation. Primary radical production reactions are those where radicals are formed from non-radical precursors. Secondary radical production or radical propagation reactions, such as Reaction (R8), are those in which radicals are changed from one species to another with no net total radical formation or loss. The dominant tropospheric primary radical production mechanism is the photolysis of $\mathrm{O}_{3}$ to yield an excited oxygen atom $\left(\mathrm{O}^{1} \mathrm{D}\right)$, which subsequently reacts with water vapor $\left(\mathrm{H}_{2} \mathrm{O}\right)$ to produce two $\mathrm{OH}$ radicals (Levy, 1972). This primary radical production of $\mathrm{OH}$ generally decreases during winter due to reduced actinic flux, shorter duration of sunlight, and substantially reduced water vapor concentrations (Spivakovsky et al., 2000). Reduced rates of $\mathrm{OH}$ production from $\mathrm{O}_{3}$ photolysis can lead to 
the increased significance of other radical production mechanisms, such as the reaction of $\mathrm{O}_{3}$ with alkenes and other photolytic sources. Three such radical production mechanisms that are significant to this work are the radical channel in the photolysis of formaldehyde (HCHO) (R11) (radical quantum yield $\varphi \sim 0.7$, Sander et al., 2011), photolysis of nitrous acid (HONO) (Reaction R12) and photolysis of nitryl chloride $\left(\mathrm{ClNO}_{2}\right)$ (Reaction R13), the latter producing a chlorine $(\mathrm{Cl})$ radical instead of $\mathrm{OH}$ or $\mathrm{HO}_{2}$ (Osthoff et al., 2008; Thornton et al., 2010).

$$
\mathrm{HCHO} \stackrel{h v, \mathrm{O}_{2}}{\longrightarrow} \mathrm{CO}+\mathrm{HO}_{2}+\mathrm{HO}_{2}
$$

$\mathrm{HONO} \stackrel{h v}{\longrightarrow} \mathrm{NO}+\mathrm{OH}$

$\mathrm{ClNO}_{2} \stackrel{h v}{\longrightarrow} \mathrm{NO}_{2}+\mathrm{Cl}^{\bullet}$

$\mathrm{HCHO}$ is predominantly produced as a gas phase oxidation product of a wide variety of VOCs (Lowe and Schmidt, 1983; Fried et al., 2003), although primary emissions have also been identified, for example from incomplete combustion (Altshuller, 1993; Olaguer et al., 2009) and snowpack photochemistry (Sumner and Shepson, 1999; Grannas et al., 2007). Photolysis of HONO produced from the reaction of $\mathrm{OH}$ with NO (Reaction R14) is not technically a radical source, with HONO instead acting as a radical reservoir. Production of $\mathrm{HONO}$ via heterogeneous uptake of $\mathrm{NO}_{2}$ and subsequent hydrolysis (stoichiometry shown in Reaction R15) (FinlaysonPitts et al., 2003), however, does result in primary radical production. This heterogeneous reaction normally occurs at the ground surface; thus HONO often exhibits vertical gradients, with the largest concentrations observed at surface level (Wong et al., 2011). Several studies have also suggested the importance of photoenhanced heterogeneous reactions of $\mathrm{NO}_{2}$ as a significant daytime source of $\mathrm{HONO}$ (Stemmler et al., 2006; Ammar et al., 2010; Monge et al., 2010). Production of $\mathrm{ClNO}_{2}$ occurs via uptake of $\mathrm{N}_{2} \mathrm{O}_{5}$ to chloride containing aerosol (Roberts et al., 2009), although it may also occur via deposition to the ground. While less is known about vertical gradients in $\mathrm{ClNO}_{2}$, the existing vertically resolved measurements of this compound suggest that it does not have a dominant surface source (Young et al., 2012).

$$
\mathrm{OH}+\mathrm{NO}+\mathrm{M} \longrightarrow \mathrm{HONO}+\mathrm{M}
$$

$2 \mathrm{NO}_{2}+\mathrm{H}_{2} \mathrm{O} \longrightarrow \mathrm{HONO}+\mathrm{HNO}_{3}$

$$
\mathrm{N}_{2} \mathrm{O}_{5}+\mathrm{Cl}_{(\mathrm{aq})}^{-} \longrightarrow \mathrm{ClNO}_{2}+\mathrm{NO}_{3(\mathrm{aq})}^{-}
$$

$\mathrm{O}_{3}$ pollution events are usually considered an urban summertime phenomenon. Anthropogenic emissions of both $\mathrm{NO}_{\mathrm{x}}$ and volatile organic compounds (VOCs), combined with high photolysis rates results in rapid radical production (EPA,
1986). Recently, however, $\mathrm{O}_{3}$ mixing ratios significantly above the current EPA National Ambient Air Quality Standards (NAAQS) of $75 \mathrm{ppb}$ ( $8 \mathrm{~h}$ average) have been observed during the wintertime in both Wyoming's Upper Green River basin (Schnell et al., 2009; Carter and Seinfeld, 2012) and Utah's Uintah Basin (Martin et al., 2011). In contrast to urban summertime $\mathrm{O}_{3}$ pollution events, these wintertime episodes occur during the darker months of the year in sparsely populated regions removed from the typical urban emissions of $\mathrm{O}_{3}$ precursor species. Both the Upper Green River basin and the Uintah Basin are regions of extensive oil and gas production, the emissions from which are currently poorly constrained (Katzenstein et al., 2003; Petron et al., 2012; Gilman et al., 2013).

In order to design the most effective wintertime $\mathrm{O}_{3}$ pollution mitigation strategies, a sound understanding of the underlying physical and photochemical processes is required. Recent work has shown that high wintertime $\mathrm{O}_{3}$ in regions of oil and gas extraction coincide with periods when the ground is snow covered, and cold stagnant weather conditions confine surface emissions to a shallow boundary layer with little advection (Schnell et al., 2009; Martin et al., 2011; Carter and Seinfeld, 2012). The role of snow cover remains uncertain, with possible mechanisms that could influence $\mathrm{O}_{3}$ concentrations including increased photolysis rates from a higher surface albedo, reduced rates of surface deposition, and the emission of reactive species from snowpack photochemistry (Grannas et al., 2007). Stable meteorology acts to increase the surface level concentrations of emitted $\mathrm{O}_{3}$ precursors through confinement to a shallower boundary layer, and also rules out stratospheric intrusions as the source of $\mathrm{O}_{3}$. The sensitivities of the $\mathrm{O}_{3}$ production photochemistry are, however, far from understood. Carter and Seinfeld (2012) performed box model calculations based on a lumped chemistry scheme investigating the sensitivities of $\mathrm{O}_{3}$ production to $\mathrm{VOC}$ and $\mathrm{NO}_{\mathrm{x}}$ concentrations during four separate case studies of $\mathrm{O}_{3}$ events in the Upper Green River basin. In three of these studies, $\mathrm{O}_{3}$ production was found to be highly sensitive to VOC and HONO concentrations, whilst the fourth case was most sensitive to $\mathrm{NO}_{\mathrm{x}}$. The difference in sensitivities between these case studies is attributed largely to differences in the observed VOC speciation at the different sites, and highlights the importance of increased observations of $\mathrm{O}_{3}$ precursors in regions of extensive oil and gas production.

The Uintah Basin has seen significantly less research into the causes of its winter $\mathrm{O}_{3}$ pollution than the Upper Green River basin, despite experiencing $\mathrm{O}_{3}$ mixing ratios well above the 75 ppbv NAAQS for multiple days during the winters of both 2009-2010 and 2010-2011 (there were no measurements during prior winters there). This paper presents a box model analysis of an extensive data set collected in the Uintah Basin during the Uintah Basin Winter Ozone Study (UBWOS) in the winter of 2011-2012. Using a near-explicit chemical oxidation scheme of $>40$ measured VOCs, this 
work aims to improve our understanding of wintertime $\mathrm{O}_{3}$ production in general and in the Uintah Basin in particular.

\section{Field campaign}

The Uintah Basin has approximately 8000 gas and 2000 oil wells currently in operation (Fig. 1). A wide range of instruments, from multiple institutions, measured boundary layer chemical composition and physical parameters at several different locations within the basin (see Supplement Table S1 for listing of observations used in this analysis). The most extensive suite of measurements was made at the Horse Pool site $\left(40.1428^{\circ} \mathrm{N} ; 109.4680^{\circ} \mathrm{W} ; 1530 \mathrm{~m}\right.$ elevation), located on the northern edge of the largest gas field in the basin (Fig. 1).

\subsection{Description of UBWOS 2012 data}

Measurements at Horse Pool were made continuously between 15 January and 1 March, the time period during which $\mathrm{O}_{3}$ pollution events were observed during the previous two winters. In contrast to the previous two years, the winter of 2011-2012 was unusually warm and dry, with no snow cover in the Uintah Basin and no stable cold-pool inversion events. Figure 2 shows $\mathrm{O}_{3}$ mixing ratio observations made at the Horse Pool site during UBWOS 2012 (red) and during the same time period in early 2011 (blue) (Martin et al., 2011). The 2011 observations show several periods of elevated $\mathrm{O}_{3}$, with mixing ratios continuously above the NAAQS for multiple days. Throughout January and February 2011 the Uintah Basin was snow covered, and the periods of high $\mathrm{O}_{3}$ coincided with stable, high-pressure weather systems, resulting in shallow boundary layer cold-pool conditions (Martin et al., 2011). $\mathrm{O}_{3}$ mixing ratios did not exceed 50 ppbv throughout the UBWOS 2012 measurement period consistent with the lack of conditions required for wintertime $\mathrm{O}_{3}$ pollution events.

Although no $\mathrm{O}_{3}$ pollution events were observed during the UBWOS 2012 observational period, a comprehensive set of measurements was made. Continuous measurements of $>60$ speciated VOCs have shown exceptional levels in the Uintah Basin, with a campaign average VOC mixing ratio of approximately $230 \mathrm{ppbv}(2080 \mathrm{ppbC})$. Observations of $\mathrm{NO}_{\mathrm{x}}$ and $\mathrm{NO}_{\mathrm{y}}$ (total reactive nitrogen) compounds also indicate a significant source of reactive nitrogen within the basin, with a campaign average $\mathrm{NO}_{\mathrm{x}}$ mixing ratio of $6 \mathrm{ppbv}$ at the Horse Pool site. These measurements provide the most detailed data set to date of atmospheric chemical composition in a region of high oil and gas production during the wintertime.

A box model using a comprehensive chemistry scheme constrained to the observed concentrations of $\mathrm{O}_{3}$ precursor species has been used to simulate an average UBWOS 2012 day (Sect. 3). This average diurnal approach was chosen to reduce the effects on the observed $\mathrm{O}_{3}$ production of the day-

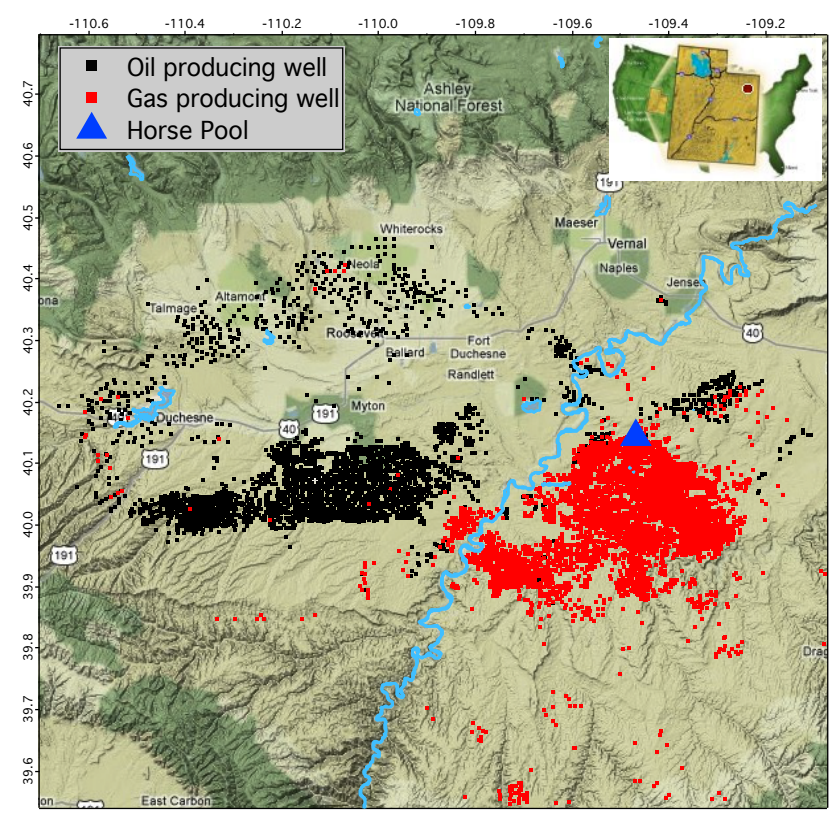

Fig. 1. Map showing location of the Uintah Basin (Red dot in top right inset), and location of the Horse Pool measurement site (blue triangle) in relation to the current oil (black) and gas (red) wells in the basin.

to-day variability due to transport processes. As current understanding of the chemistry causing these wintertime $\mathrm{O}_{3}$ pollution events is highly uncertain, simulating the average UBWOS 2012 day simplifies the problem enabling a focused study of the $\mathrm{O}_{3}$ photochemistry. The calculated average day is used to understand the key chemical processes controlling $\mathrm{O}_{3}$ production in this environment (Sects. 4-6). The model also enables the investigation of some of the mechanisms thought to cause the high $\mathrm{O}_{3}$ observed in 2010 and 2011 (Sect. 7).

\subsection{Description of model}

Model simulations were performed using the Dynamically Simple Model of Atmospheric Chemical Complexity (DSMACC) (Emmerson and Evans, 2009; Stone et al., 2010; Edwards et al., 2012). This zero dimensional model is constrained to the observed concentrations of $\mathrm{H}_{2} \mathrm{O}, \mathrm{CO}$, methane $\left(\mathrm{CH}_{4}\right)$, VOCs, oxygenated VOCs (OVOCs), HONO, and $\mathrm{ClNO}_{2}$, as well as the physical parameters of temperature and pressure (S2). The diurnally averaged data used to constrain the model are first filtered to exclude periods of high wind speed in order to capture the quiescent periods during UBWOS 2012, thus removing periods of strong dilution when $\mathrm{O}_{3}$ production cannot be described by in situ chemistry. This filter removes data when wind speeds were above the $2 \sigma$ value from a Gaussian fit to the low wind speed distribution (S3), corresponding to a wind speed of $4.4 \mathrm{~m} \mathrm{~s}^{-1}$. Exclusion of the higher wind data removes approximately $10 \%$ of the 


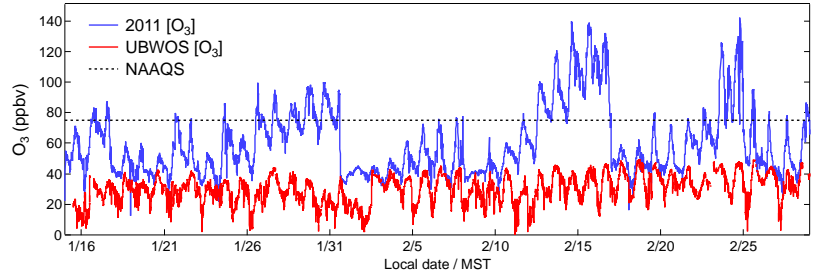

Fig. 2. Observed $\mathrm{O}_{3}$ mixing ratios at the Horse Pool site between 15 January-1 March 2011 (blue) and 2012 (red). The dashed black line shows the EPA $8 \mathrm{~h}$ average NAAQS of $75 \mathrm{ppbv}$.

entire data set. In order for $\mathrm{NO}_{\mathrm{x}}$ concentrations to be consistent with the model chemistry scheme, model $\mathrm{NO}_{\mathrm{x}}$ is constrained by the use of an emission of $\mathrm{NO}$ which is tuned to best match the observed $\mathrm{NO}$ and $\mathrm{NO}_{2}$ concentrations. Photolysis frequencies are calculated using a surface albedo of 0.1 , an $\mathrm{O}_{3}$ column density of 260 Dobson units, and the TUV radiation model (Madronich, 1998). The calculated photolysis frequencies are then scaled to the campaign average $j\left(\mathrm{O}^{1} \mathrm{D}\right)$ and $j\left(\mathrm{NO}_{2}\right)$ observations, with the ratio between the measured and calculated $j\left(\mathrm{NO}_{2}\right)$ being applied to all calculated photolysis rates other than $j\left(\mathrm{O}^{1} \mathrm{D}\right)$.

The model chemistry scheme is generated by the Master Chemical Mechanism (MCM) V3.2 (Jenkin et al., 1997; Saunders et al., 2003) and contains detailed inorganic chemistry and a near-explicit degradation scheme for 44 of the observed VOCs and OVOCs displayed in Supplement S2, resulting in 3180 species and 12447 reactions. As the MCM does not contain explicit oxidation schemes for the 7 substituted cyclo-alkanes observed (Listed in S2(c)), these compounds have been lumped as cyclohexane for the simulations described here. The MCM chemistry scheme has been modified to include the photolysis of $\mathrm{ClNO}_{2}$ to yield a chlorine radical $(\mathrm{Cl})$. The $\mathrm{ClNO}_{2}$ photolysis frequency has been parameterized as a linear combination of $j\left(\mathrm{O}^{1} \mathrm{D}\right)$ and $j\left(\mathrm{NO}_{2}\right)$ using the absorption cross-section data reported by Ghosh et al. (2011). The MCM v3.2 only includes $\mathrm{Cl}$ kinetics and mechanisms for alkanes. In order to assess the importance of this limited $\mathrm{Cl}$ chemistry scheme on the conclusions of this work, a model simulation has been performed including extra inorganic $\mathrm{Cl}$ reactions and $\mathrm{Cl}$ oxidation mechanisms for methanol, ethanol, isopropanol, $\mathrm{HCHO}$, acetone, acetaldehyde, ethene, and toluene (S4). The inclusion of these extra $\mathrm{Cl}$ reactions results in a $<1 \%$ change in calculated $\mathrm{O}_{3}$ and $\mathrm{OH}$ radical concentrations within the model. This lack of sensitivity to additional $\mathrm{Cl}$ reactions is due to the unusually large VOC concentrations observed during UBWOS 2012, in particular those of alkanes (Fig. 3a), resulting in a $\mathrm{Cl}$ reactivity of approximately $700 \mathrm{~s}^{-1},>95 \%$ of which is due to reaction with the observed alkanes in the expanded chemistry scheme simulation. The negligible effect of an expanded $\mathrm{Cl}$ chemistry scheme on calculated $\mathrm{O}_{3}$ production chemistry for UBWOS 2012 conditions means that for simplicity the
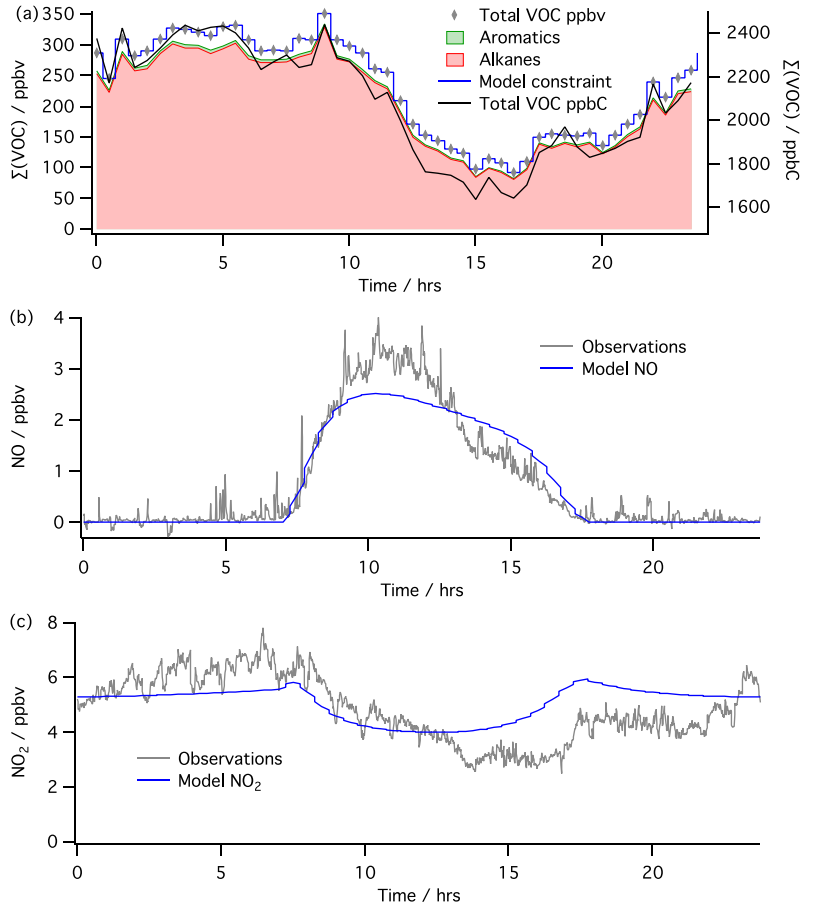

Fig. 3. (a) Summed VOC observations (grey diamonds) and model constraint (blue), with shading indicating contribution from alkanes and aromatics. The observed VOC mixing ratio in ppbC (black) is shown on the right axis. (b) $\mathrm{NO}$ and (c) $\mathrm{NO}_{2}$ average diurnal observations at Horse Pool measurement site (grey) and model simulated mixing ratios (blue) using a fixed NO source with the partitioning between reactive nitrogen species calculated by the chemistry scheme.

chemistry scheme used for the work presented in this paper only includes the reactions of $\mathrm{Cl}$ included in the MCM v3.2.

The model is integrated forward with a time step of $600 \mathrm{~s}$ until the concentrations are found to be in a diurnal steady state, i.e., when the cycles of simulated species exhibit less than $0.01 \%$ variation from the previous day. For all the simulations shown here, diurnal steady state was reached prior to day 7; however, as the time taken to reach diurnal steady state varies depending on the model conditions, day 10 of the forward running integration has been used for all model calculated days for consistency. In order to represent the nonchemical loss of species either through deposition or mixing, and thus prevent the accumulation of unconstrained species within the model, a lifetime with respect to a physical first order loss of $24 \mathrm{~h}\left(k_{\text {loss }}=1.15 \times 10^{-5} \mathrm{~s}^{-1}\right.$, equivalent to a deposition velocity of $V_{\mathrm{d}}=1.15 \mathrm{~cm} \mathrm{~s}^{-1}$ in a $1000 \mathrm{~m}$ deep boundary layer) is applied to all calculated species other than $\mathrm{O}_{3}$ and nitric acid $\left(\mathrm{HNO}_{3}\right)$. Model simulations where $k_{\text {loss }}$ is varied show that, although the absolute $\mathrm{O}_{3}$ concentration calculated is affected by the $k_{\text {loss }}$ value chosen, the conclusions based on the sensitivities of the chemistry described in the subsequent sections of this paper still apply. The physical 
loss rates used for $\mathrm{O}_{3}$ and $\mathrm{HNO}_{3}$ in the model are different from $k_{\text {loss }}$, as observations of these species allow better constraint of this parameter. For $\mathrm{HNO}_{3}$ a value of $5 \times 10^{-5} \mathrm{~s}^{-1}$ was chosen, as this is within the range of observed deposition velocities reported in the literature and provides a calculated concentration of $\mathrm{HNO}_{3}$ that agrees with the observations to within a factor of 2 . The $\mathrm{O}_{3}$ physical loss rate of $4.4 \times 10^{-6} \mathrm{~s}^{-1}$ was chosen based on calculations of nighttime $\mathrm{O}_{3}$ removal and the observed $\mathrm{NO}_{\mathrm{x}}$ concentrations, assuming the only nocturnal losses of $\mathrm{O}_{3}$ are reaction with $\mathrm{NO}_{\mathrm{x}}$ and physical removal. Physical removal of ozone most likely proceeds via deposition to the surface.

\section{The base model simulation}

In order to best represent the $\mathrm{O}_{3}$ photochemistry during UBWOS 2012, the model concentrations of the observed VOCs, and the radical precursors $\mathrm{HCHO}, \mathrm{HONO}$ and $\mathrm{ClNO}_{2}$ are forced to match the measured diurnal profiles. Each of the measured speciated VOCs and radical precursors are constrained to 30 minute average diurnal observations, with any species without an explicit oxidation mechanism lumped as described in Sect. 2.2. Figure 3a shows the observed diurnal average total non-methane hydrocarbon mixing ratio to which the model is constrained, with the alkane and aromatic fractions indicated. As the model does not represent any dynamical processes, constraining to the observed VOC diurnal profiles in this way reduces the impact of not considering mixing on the in situ $\mathrm{O}_{3}$ production. The effect of mixing can be seen in the reduction in observed VOC mixing ratios in the afternoon, due to dilution during boundary layer break up. This afternoon reduction is similar to that observed in stable trace gases, such as $\mathrm{CO}_{2}$ and methane, and most likely does not result from chemical transformation such as VOC oxidation.

An emission of NO is used to best reproduce $\mathrm{NO}$ and $\mathrm{NO}_{2}$ at the Horse Pool site. This method of representing $\mathrm{NO}_{\mathrm{x}}$ was chosen over constraining to either of the observed $\mathrm{NO}_{\mathrm{x}}$ species concentrations, as conceptually this best represents the true $\mathrm{NO}_{\mathrm{x}}$ source within the basin whilst still being consistent with the chemistry scheme. Figure $3 \mathrm{~b}$ and $\mathrm{c}$ show the average diurnal $\mathrm{NO}$ and $\mathrm{NO}_{2}$ observations (grey) compared with the model calculated $\mathrm{NO}_{\mathrm{x}}$ mixing ratios (blue).

Figure 4 compares the observed average diurnal $\mathrm{O}_{3}$ mixing ratio with that calculated by the observationally constrained base model simulation. The model does a reasonable job of simulating the observed $\mathrm{O}_{3}$ profile, with the daily mean calculated $\mathrm{O}_{3}$ mixing ratio agreeing with the observations to within $10 \%$ and accounting for $85 \%$ of the observed daily average $16 \mathrm{ppbv}$ rise in $\mathrm{O}_{3}$ mixing ratio. The model under-prediction, largest in the afternoon, is most likely attributable to mixing of $\mathrm{O}_{3}$ rich air from above during boundary layer breakup. Diurnally averaged $\mathrm{O}_{3}$ observations made at a height of $500 \mathrm{~m}$ from a balloon platform between 1 and

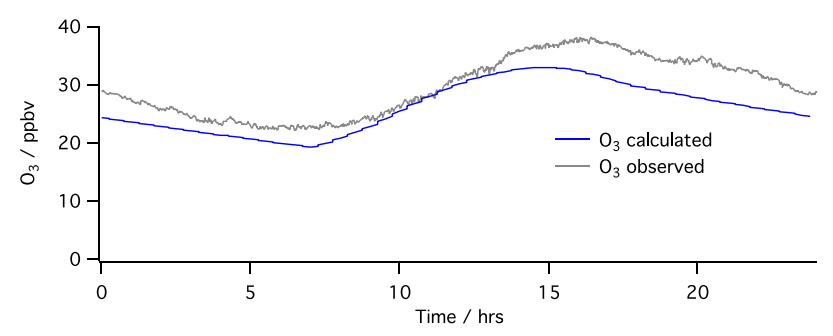

Fig. 4. Observed diurnal $\mathrm{O}_{3}$ profile (grey) and fully constrained base model calculated (blue).

22 February indicate that photochemical $\mathrm{O}_{3}$ production accounted for approximately $70 \%$ of the observed $\mathrm{O}_{3}$ increase during this period, although this number is highly uncertain due to the large amount of observed variability in both vertical $\mathrm{O}_{3}$ and mixing depth.

Agreement between the calculated and observed $\mathrm{O}_{3}$ mixing ratios gives confidence that the model is simulating the $\mathrm{O}_{3}$ photochemistry satisfactorily. The model can therefore be used to investigate the sensitivities to various aspects of the chemistry controlling $\mathrm{O}_{3}$ production in the snow-free wintertime Uintah Basin. In the following sections we examine the sources and sinks of the radicals that drive the $\mathrm{O}_{3}$ production chemistry, allowing us to determine the VOC and $\mathrm{NO}_{\mathrm{x}}$ sensitivity of the $\mathrm{O}_{3}$ production observed during UBWOS 2012. In the final section of the paper we use the model to simulate the $\mathrm{O}_{3}$ photochemistry that might be expected under cold-pool conditions, to test if the chemistry observed during UBWOS 2012 can explain the high $\mathrm{O}_{3}$ concentrations seen during the winters of 2009-2010 and 2010-2011.

\section{Radical sources}

In addition to VOCs and $\mathrm{NO}_{\mathrm{x}}$, tropospheric $\mathrm{O}_{3}$ production is dependent on radicals to drive the oxidation cycles that convert $\mathrm{NO}$ to $\mathrm{NO}_{2}$ (Reactions R3-R8). Identifying the important radical sources is therefore essential if we are to understand $\mathrm{O}_{3}$ production during UBWOS 2012. Figure 5 shows the diurnal production rates of both $\mathrm{OH}$ and $\mathrm{Cl}$ radicals from primary sources within the constrained model simulated day. In Fig. 5 both $\mathrm{HCHO}$ and $\mathrm{HONO}$ are treated as primary radical sources, as unconstrained simulations (Figs. 6-7) show the chemistry scheme does not accurately predict their observed mixing ratios, implying either a primary emission or an unknown source mechanism. The HONO produced from the reaction of $\mathrm{OH}+\mathrm{NO}$ within the model $(40 \%$ of the observed mixing ratio) has been subtracted from the $\mathrm{OH}$ production due to the photolysis of the observed HONO (dashed red line). Production and loss of $\mathrm{HONO}$ through $\mathrm{OH}+\mathrm{NO}$ and photolysis is a null cycle that does not represent net primary $\mathrm{OH}$ production, while HONO photolysis in excess of this amount may be considered a primary radial source. Subtracting the non-primary $\mathrm{HCHO}$ source from the observed 


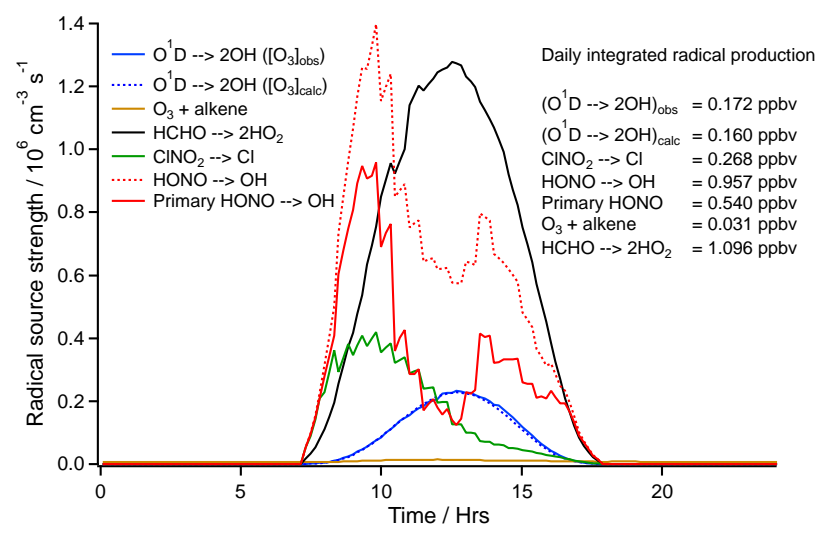

Fig. 5. Primary radical source strengths in constrained model simulation. Primary HONO (solid red line) is calculated by subtraction of $\mathrm{HONO}$ formed by $\mathrm{OH}+\mathrm{NO}$ from the $\mathrm{OH}$ produced from photolysis of the observed HONO (dashed red line). All the observed $\mathrm{HCHO}$ has been considered as a primary source in this analysis. The textbox also shows the daily-integrated radical production from each source.

is much more difficult, as concentrations of HCHO are often miscalculated by current chemistry schemes (Zhou et al., 1996; Frost et al., 2002; Fried et al., 2003; Riedel et al., 2005; Jones et al., 2009). Observations of HCHO during UBWOS 2012 indicate contributions from both direct emission and photochemical production. Spikes in HCHO were found to correlate with methanol concentrations, indicating a common primary source; methanol is used for dehydration and de-icing during Oil and Natural Gas extraction and to prevent the formation of hydrates. Primary $\mathrm{HCHO}$ emissions have also been observed from petrochemical flares (Olaguer et al., 2009), providing another potential source within the Uintah Basin. The observed diurnal profile of HCHO does, however, indicate a significant photochemical source in addition to primary emission. In this simulation, photochemically produced $\mathrm{HCHO}$ accounts for $50 \%$ of the observed daily integrated mixing ratio, implying the remainder comes either from a primary emission or from an underestimation of the production of $\mathrm{HCHO}$ by the model chemistry scheme. Unlike $\mathrm{HONO}, \mathrm{HCHO}$ is produced as the stable reaction product along with $\mathrm{HO}_{2}$ in radical propagation reactions, and is therefore a radical amplification mechanism and not a radical reservoir. A radical amplification mechanism is one in which a radical is needed to initiate the reaction, but more radicals are produced in subsequent steps than consumed in the initiation. For this reason we have treated the photolysis of the observed $\mathrm{HCHO}$ concentration as a primary radical source in this analysis. As the model calculates the $\mathrm{O}_{3}$ concentration, the production rate of $\mathrm{OH}$ from $\mathrm{O}^{1} \mathrm{D}+\mathrm{H}_{2} \mathrm{O}$ is calculated using both the calculated and observed $\mathrm{O}_{3}$ concentrations, and agree to within $7 \%$.

Early morning radical production is dominated by the photolysis of primary $\mathrm{HONO}$ and $\mathrm{ClNO}_{2}$, with $\mathrm{HCHO}$ photol-

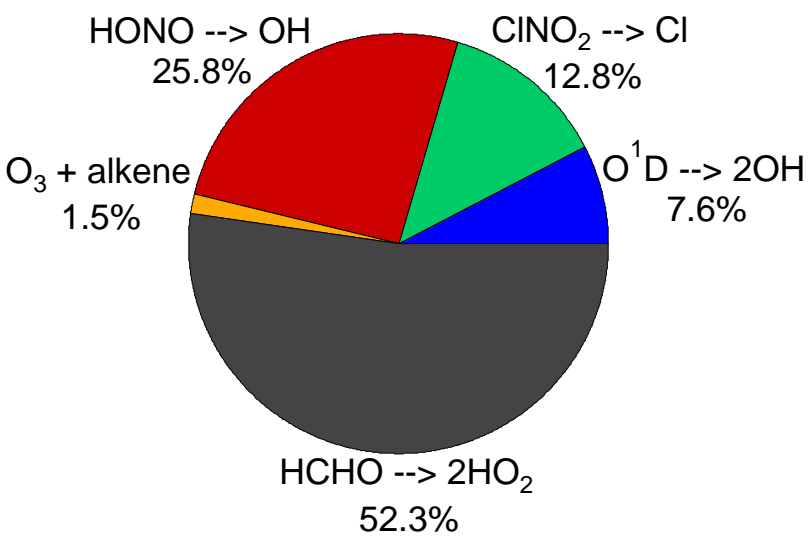

Fig. 6. Pie chart showing the relative importance of the individual primary radical sources, identified in Fig. 5, when integrated over the entire model day. The contribution from $\mathrm{O}^{1} \mathrm{D}+\mathrm{H}_{2} \mathrm{O}$ is calculated using the observed $\left[\mathrm{O}_{3}\right]$. The HONO contribution is from primary $\mathrm{HONO}$ only, i.e., with the $\mathrm{HONO}$ produced from $\mathrm{OH}+$ NO subtracted.

ysis becoming the largest single radical source by approximately 10 a.m. local time. As described in the introduction, production of HONO is thought to occur via heterogeneous uptake of $\mathrm{NO}_{2}$ to the ground surface, resulting in strong vertical gradients in its concentrations. Vertically resolved information on $\mathrm{HONO}$ and $\mathrm{ClNO}_{2}$ are not available. If $\mathrm{HONO}$ is more concentrated near the surface, while $\mathrm{ClNO}_{2}$ is more uniform throughout the boundary layer, then $\mathrm{ClNO}_{2}$ may be a larger radical source compared to HONO than represented here. The source of $\mathrm{OH}$ from $\mathrm{O}_{3}+$ alkene reactions is small throughout the day, never exceeding $1.5 \times 10^{4} \mathrm{~cm}^{-3} \mathrm{~s}^{-1}$. This low contribution from ozonolysis is due to the low emissions of alkenes from the oil and gas extraction process. The reaction of $\mathrm{O}^{1} \mathrm{D}+\mathrm{H}_{2} \mathrm{O}$, often considered the dominant daytime radical source mechanism, is also small when compared to the radical sources from $\mathrm{HONO}, \mathrm{HCHO}$ and $\mathrm{ClNO}_{2}$ photolysis. This low primary production of $\mathrm{OH}$ from $\mathrm{O}^{1} \mathrm{D}$ is due to a combination of the low wintertime $\mathrm{O}_{3}$ photolysis rates and the low water vapor concentration at cold temperatures. The relative daily-integrated radical production from each of the mechanisms identified is shown in Fig. 6.

The $\mathrm{OH}$ production rate from $\mathrm{O}^{1} \mathrm{D}+\mathrm{H}_{2} \mathrm{O}$ in this cold wintertime environment of $\sim 170 \mathrm{pptv}^{-1} \mathrm{day}^{-1}$ is low relative to summertime radical production. For comparison, during a recent field study in May-June in Pasadena, CA, the average primary $\mathrm{OH}$ production from this reaction was $\sim 10$ ppbv day $^{-1}$ (Young et al., 2012). Other radical precursor species identified in Fig. 6 therefore have a much larger role in this environment. $\mathrm{HONO}, \mathrm{HCHO}$ and $\mathrm{ClNO}_{2}$ are all constrained to their observed diurnal mixing ratio profiles in the base model simulation; however, the gas phase chemistry scheme cannot explain the observed mixing ratios of these species. The inability of the chemistry scheme to 

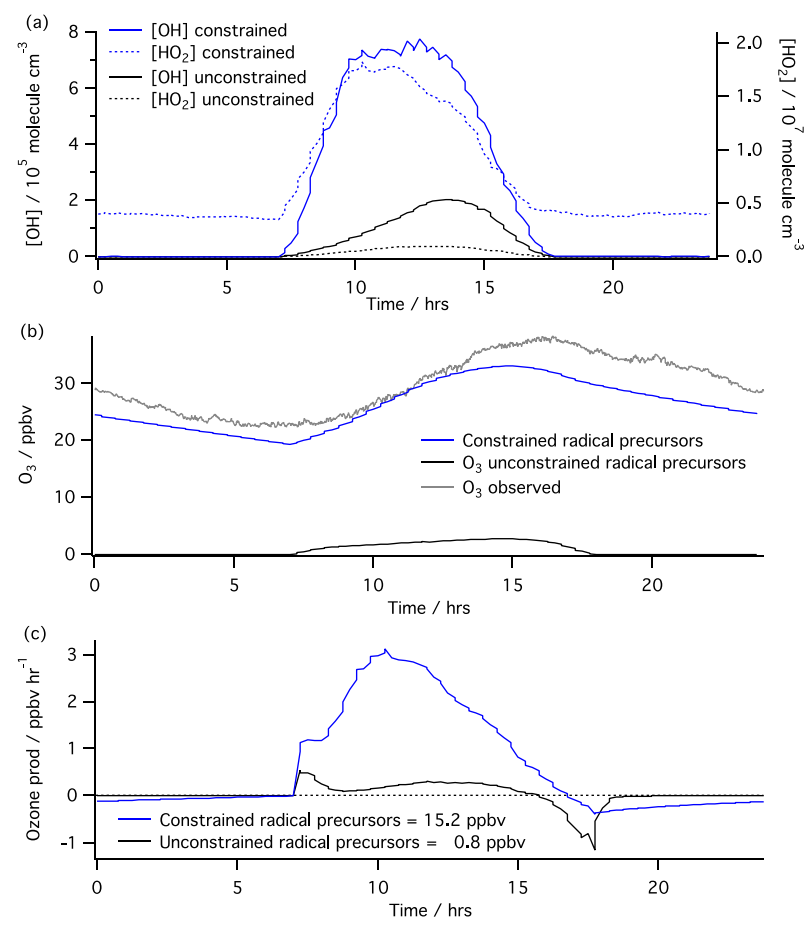

Fig. 7. $=\left(\right.$ a) $[\mathrm{OH}]$ (solid lines) and $\left[\mathrm{HO}_{2}\right]$ (dashed lines) and (b) $\mathrm{O}_{3}$ for the model simulation constrained to the observed diurnal average mixing ratios of the radical precursor species $\mathrm{HCHO}, \mathrm{HONO}$ and $\mathrm{ClNO}_{2}$ (blue) and the simulation where these species are calculated by the chemistry scheme (black). (c) $\mathrm{O}_{3}$ production rate for the two simulations, offset to zero $\mathrm{ppbv} \mathrm{h}^{-1}$ at sunrise.

simulate the concentrations of the radical precursors HCHO, $\mathrm{HONO}$ and $\mathrm{ClNO}_{2}$ is due largely to a lack of knowledge about their sources, in particular those of $\mathrm{HONO}$ and $\mathrm{ClNO}_{2}$ which are thought to be dominated by heterogeneous process (see Sect. 1) that are not represented in the MCM v3.2 chemistry scheme used in this work. For $\mathrm{HCHO}$ it is likely that a primary emission within the Uintah Basin that is not described within the model accounts for a significant fraction of the HCHO source (see Sect. 4). A simulation that does not contain any $\mathrm{ClNO}_{2}$, and that allows the chemistry scheme to calculate $\mathrm{HCHO}$ (i.e., from VOC oxidation with no additional $\mathrm{HCHO}$ prescribed by the model) and HONO (i.e., from $\mathrm{OH}+\mathrm{NO}$ alone, with no primary $\mathrm{OH}$ source from HONO photolysis), calculates significantly lower radical concentrations (Fig. 7a). This decrease in radical concentration results in a collapse of the calculated $\mathrm{O}_{3}$ mixing ratio to zero at night and $2.8 \mathrm{ppbv}$ maximum at 14:45 during late afternoon (Fig. 7b). The response of the calculated $\mathrm{O}_{3}$ is due to insufficient radicals to drive the oxidation of $\mathrm{NO}$ to $\mathrm{NO}_{2}$ resulting in reduced $\mathrm{O}_{3}$ production. As a consequence of the reduced rate of $\mathrm{NO}$ to $\mathrm{NO}_{2}$ conversions, the $\mathrm{O}_{3}$ that is generated is rapidly titrated by NO. Figure $7 \mathrm{c}$ shows the calculated $\mathrm{O}_{3}$ production in ppbv $\mathrm{h}^{-1}$ for the two simulations, with and without the constrained radical precursor concen- trations. The $\mathrm{O}_{3}$ production rates for both simulations have been equated to zero at sunrise to enable a direct comparison of the daytime $\mathrm{O}_{3}$ production, whilst minimizing the effects of model parameters such as $\mathrm{O}_{3}$ deposition rates, which can impact the absolute calculated $\mathrm{O}_{3}$ mixing ratio. Integrating under these $\mathrm{O}_{3}$ production curves yields a total $\mathrm{O}_{3}$ production of $15.2 \mathrm{ppbv} \mathrm{day}^{-1}$ for the base simulation, compared to $0.81 \mathrm{ppbv}^{-1 a y^{-1}}$ for the simulation with no $\mathrm{ClNO}_{2}$ and unconstrained $\mathrm{HONO}$ and $\mathrm{HCHO}$.

The $\mathrm{O}_{3}$ collapse shown in Fig. 7 highlights the importance of $\mathrm{HONO}, \mathrm{HCHO}$ and $\mathrm{ClNO}_{2}$ as radical sources in this environment. Figure 8 shows simulations where the mixing ratios of $\mathrm{HONO}, \mathrm{HCHO}$ and $\mathrm{ClNO}_{2}$ are individually unconstrained from the observations, illustrating the relative importance of these three radical precursors on $\mathrm{O}_{3}$ production. The largest reduction in $\mathrm{O}_{3}$ production comes from removing the $\mathrm{HCHO}$ constraint, resulting in a $40 \%$ reduction in calculated peak $\mathrm{O}_{3}$ concentration and a $26 \%$ reduction in $\mathrm{O}_{3}$ production. This large effect of removing the HCHO constraint is expected as $\mathrm{HCHO}$ accounts for the largest single primary radical source (Fig. 6) and approximately $50 \%$ of the observed mixing ratio cannot be explained by in situ photochemical production. Removing either the $\mathrm{ClNO}_{2}$ or the HONO constraints reduces the peak $\mathrm{O}_{3}$ concentration by approximately $20 \%$ and the calculated $\mathrm{O}_{3}$ production by approximately $13 \%$. If $\mathrm{ClNO}_{2}$ is unconstrained the entire $\mathrm{Cl}$ radical source within the model disappears, $12.8 \%$ of the total primary radical production (Fig. 6), as the chemistry scheme does not include a mechanism for $\mathrm{ClNO}_{2}$ production. Although the contribution of HONO to the total primary radical source is larger than that of $\mathrm{ClNO}_{2}$ (25.8\% compared with $\left.12.8 \%\right)$ the effect of unconstraining its concentration has a similar effect on total daily $\mathrm{O}_{3}$ production within the model. This is largely due to the difference in the reactions of $\mathrm{OH}$ and $\mathrm{Cl}$ radicals, with essentially all the $\mathrm{Cl}$ radicals reacting with VOCs in contrast to $\mathrm{OH}$ where reactions with $\mathrm{NO}_{\mathrm{x}}$ are a significant sink (see Sect. 6). In the unconstrained HONO simulation the nighttime HONO essentially disappears, resulting in a $95 \%$ reduction in HONO mixing ratios relative to the observations at sunrise. After the large discrepancy between calculated and observed HONO in the morning, photochemical production of HONO (Reaction R14) in the afternoon accounts for up to $85 \%$ of the observed mixing ratio. This results in the $\mathrm{O}_{3}$ production rate in the afternoon in the unconstrained HONO simulation being similar to that in the base simulation, indicating that the concentrations of HONO observed in the afternoon are in photochemical steady state.

\section{Influence of VOC speciation}

As well as the primary radical sources described in the previous section, multiple radical amplification reactions contribute to the total radical source, and thus $\mathrm{O}_{3}$ production. These radical amplification reactions are particularly 

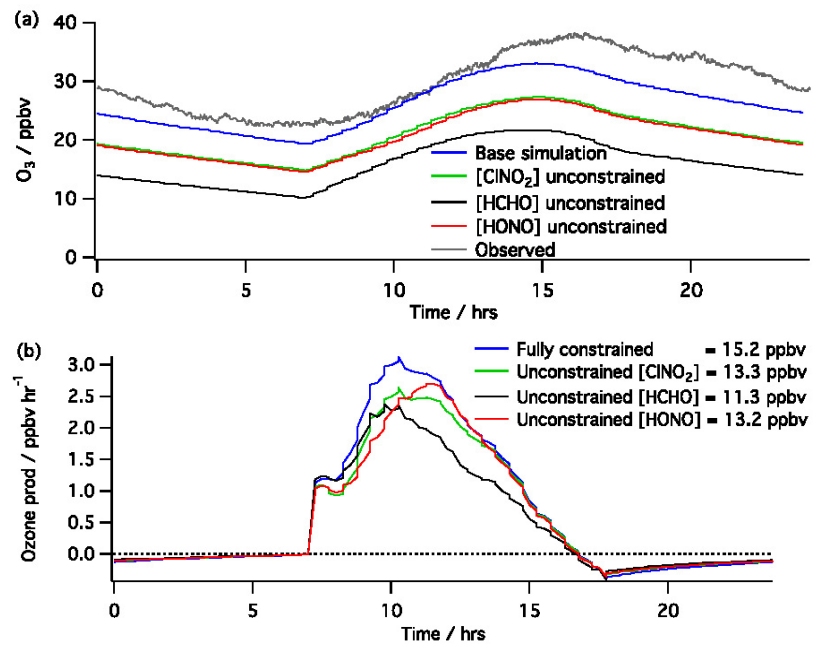

Fig. 8. (a) $\mathrm{O}_{3}$ mixing ratios and (b) $\mathrm{O}_{3}$ production rates calculated for simulations where the mixing ratios of the radical precursors $\mathrm{HONO}, \mathrm{HCHO}$ and $\mathrm{ClNO}_{2}$ are independently unconstrained.

significant in the oxidation of substituted aromatic compounds, such as m-xylene (Reactions R17-R21), where unsaturated, photolabile species are produced as the stable product in reaction propagation steps (e.g., Reaction R19). These stable reaction products subsequently photolyze to produce additional radicals, thereby amplifying the radical concentration. This type of radical amplification process contributes to the large photochemical ozone creation potentials of substituted aromatic compounds reported in the previous studies of the impact of VOC speciation on $\mathrm{O}_{3}$ production (Hough and Derwent, 1987; Andersson-Sköld et al., 1992; Derwent et al., 1996, 1998; Jiang et al., 1997; Jenkin et al., 2003).
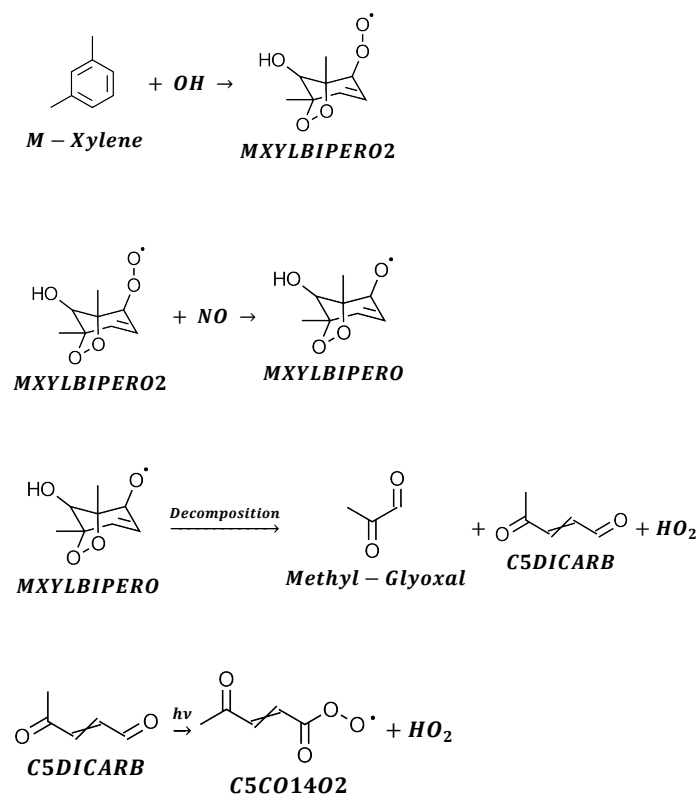

$$
\prod_{\mathrm{O}}^{\mathrm{O}} \stackrel{h v}{\rightarrow} \underset{\mathrm{O}}{\mathrm{CH}_{\mathrm{O} O \mathrm{O}} \mathrm{O}^{\cdot}}+\mathrm{CO}+\mathrm{HO}_{2}
$$

Reactions (17)-(21): one of the oxidation pathways for $\mathrm{m}$ xylene in the MCM chemistry scheme, with MCM species names, showing the potential for radical amplification through the generation of photolabile species. This set of 5 reaction steps has the potential to generate 5 peroxy radicals for each $\mathrm{OH}$ initiation. The photolysis of the C5DICARB species generated in Reaction (R19) accounts for 3.8\% of the total radical source in the constrained base model simulation (Fig. 9a).

Figure 9a shows the fraction of radicals in the constrained model simulation from all net radical production mechanisms, not just the primary radical sources shown in Fig. 6 . Although still dominated by the primary radical sources of $\mathrm{HCHO}, \mathrm{HONO}$ and $\mathrm{ClNO}_{2}$, a significant fraction (26\%) of the radicals in the constrained base simulation are generated via radical amplification mechanisms. The most significant radical amplification reactions are from the oxidation of aromatic species. A simulation where all aromatic species are replaced by cyclohexane has been used to assess the importance of this chemistry on calculated $\mathrm{O}_{3}$ production. Cyclohexane was chosen as a replacement as it has a similar reactivity towards $\mathrm{OH}$ and a similar number of carbons to many of the aromatic species, but since it is a cyclic alkane its oxidation chemistry does not have radical amplification steps present in the aromatic oxidation scheme. The $\mathrm{OH}$ reactivity in this zero aromatics simulation is on average $4 \%$ lower than in the base constrained simulation, with the mean decreasing from $13.6 \mathrm{~s}^{-1}$ to $13.1 \mathrm{~s}^{-1}$ due to the higher reactivity of some of the aromatics. Figure $9 \mathrm{~b}$ shows the radical sources in this zero aromatics simulation. The area of the pie relative to Fig. 9a represents the relative daily-integrated radical production in the two simulations, approximately 2.8 ppbv day $^{-1}$ for the base simulation and $2.1 \mathrm{ppbv}^{-1 a y}{ }^{-1}$ in the zero aromatics simulation. The decrease in total radical production between the two simulations is due to the removal of radical amplification steps such as those shown in Reactions (R17)-(R21), with the non-primary component of the radical production decreasing from $20 \%$ to $2 \%$.

The reduction in total radical production in the zero aromatics simulation results in lower radical concentrations, and thus reduced ozone production. Figure 10a and b show the impact of replacing the observed aromatic VOCs with cyclohexane on the calculated $\mathrm{OH}, \mathrm{HO}_{2}$ and $\mathrm{O}_{3}$, reducing their peak concentrations by $11 \%, 28 \%$, and $16 \%$, respectively. Figure $10 \mathrm{c}$ shows the effect of this change in VOC speciation on the $\mathrm{O}_{3}$ production rate calculated in the model. The $\mathrm{O}_{3}$ production rate is unchanged between the two simulations in the early morning, when $\mathrm{HONO}$ and $\mathrm{ClNO}_{2}$ photolysis 


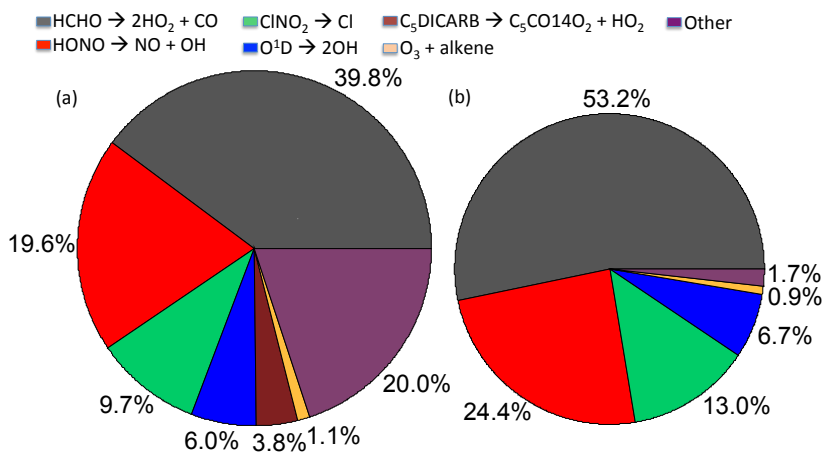

Fig. 9. Pie charts showing (a) total radical sources in the constrained model simulation and (b) the simulation in which all observed aromatic VOCs have been replaced with cyclohexane. The areas of the pies represent the relative total radical production in the two simulations. All radical reservoir cycling, from species such as PAN and $\mathrm{HO}_{2} \mathrm{NO}_{2}$, have been omitted from these charts and the $\mathrm{HONO}$ contribution is from primary HONO only, i.e., with the HONO produced from $\mathrm{OH}+\mathrm{NO}$ subtracted.

dominate the radical production. After the morning burst of radicals from these two primary radical sources, the reduction in radicals in the simulation with no aromatics results in a daily-integrated $\mathrm{O}_{3}$ production (offset to $0 \mathrm{ppbv} \mathrm{h}^{-1}$ at sunrise) reduction from $15.2 \mathrm{ppbv}$ day $^{-1}$ to $13.3 \mathrm{ppbv}^{-1} \mathrm{day}^{-1}$, a similar reduction to that seen in the simulations with unconstrained $\mathrm{ClNO}_{2}$ or $\mathrm{HONO}$ (Fig. 8).

Simulations where all aromatics were removed from the model and where the equivalent number of moles of nonaromatic VOCs were removed quantifies the modeled importance of aromatics to $\mathrm{O}_{3}$ formation in the wintertime Uintah Basin. Aromatic VOCs account for approximately $1.6 \%$ of the total observed VOC mixing ratio. Removing the aromatic species results in a drop in calculated peak $\mathrm{O}_{3}$ mixing ratio from 33.1 to $26.6 \mathrm{ppbv}$, through a $15 \%$ reduction in the calculated $\mathrm{O}_{3}$ production rate, from 15.2 to $12.9 \mathrm{ppbv}$ day $^{-1}$. Removing the same number of moles of non-aromatic VOCs (i.e., reducing all the constraining concentrations of the nonaromatic VOCs by $1.6 \%$ ) results in only a very small decrease in peak $\mathrm{O}_{3}$, to $32.8 \mathrm{ppbv}$, and a reduction in $\mathrm{O}_{3}$ production rate of $0.5 \%$ to $15.1 \mathrm{ppbv}$ day $^{-1}$. These simulations indicate that aromatic VOCs are approximately 30-40 times more effective $\mathrm{O}_{3}$ producers than the non-aromatic VOCs in this environment. Despite current uncertainties in the oxidation chemistry of aromatic compounds (Jenkin et al., 2003; Koch et al., 2007; Bohn and Zetzsch, 2012; Loison et al., 2012), the radical amplification reactions provide a mechanism by which total radical production can be increased. This can have significant implications for local $\mathrm{O}_{3}$ production in regions, such as the Uintah Basin, where aromatic VOC mixing ratios are large (UBWOS 2012 average $\sim 4$ ppbv) and primary radical production is low.
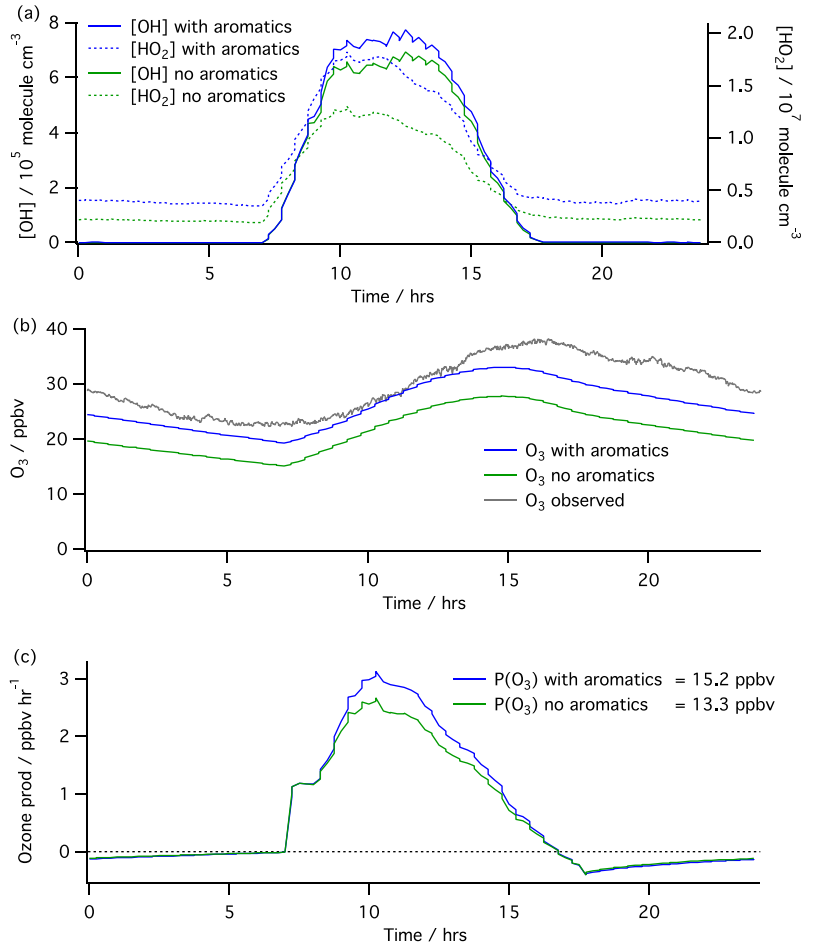

Fig. 10. $=(\mathbf{a})[\mathrm{OH}]$ (solid lines) and $\left[\mathrm{HO}_{2}\right]$ (dashed lines) and (b) $\mathrm{O}_{3}$ for the model simulation constrained to the observed diurnal average concentrations of all observed speciated VOCs (blue) and the simulation where all aromatic species are replaced with cyclohexane (green). (c) $\mathrm{O}_{3}$ production rate for the two simulations, offset to zero $\mathrm{ppbv} \mathrm{h}^{-1}$ at sunrise.

\section{Radical sinks and VOC vs. $\mathrm{NO}_{\mathrm{x}}$ limitation}

As well as identifying the important radical sources within the constrained model simulation, the model has been used to ascertain the major radical loss reactions and explore the implications for $\mathrm{O}_{3}$ production. The unusually high VOC mixing ratios observed during UBWOS 2012 (mean VOC $=230 \mathrm{ppbv}, 2080 \mathrm{ppbC}$ ) result in the $\mathrm{OH}$ and $\mathrm{Cl}$ reactivity being dominated by reaction with VOCs, in particular alkanes. Figure 11a shows the relative contributions to $\mathrm{OH}$ reactivity during the constrained model simulated day. Observed species, such as alkanes, aromatics, alkenes, oxygenates, methane, $\mathrm{NO}_{2}$, and $\mathrm{CO}$ account for $79.6 \%$ of the $\mathrm{OH}$ losses shown in Fig. 6, while model calculated intermediate species arising from the oxidation of the observed VOCs accounts for the remaining $20.4 \%$, labeled "other" in Fig. 11a. It is possible that the model calculates unmeasured VOC oxidation products incorrectly, and thus that there is some uncertainty in the $\mathrm{OH}$ reactivity. For example, simulations in which measured oxidation products such as acetaldehyde and methyl ethyl ketone were unconstrained calculated the concentrations of these products to within a factor of two of the observations. However, the model calculates a 


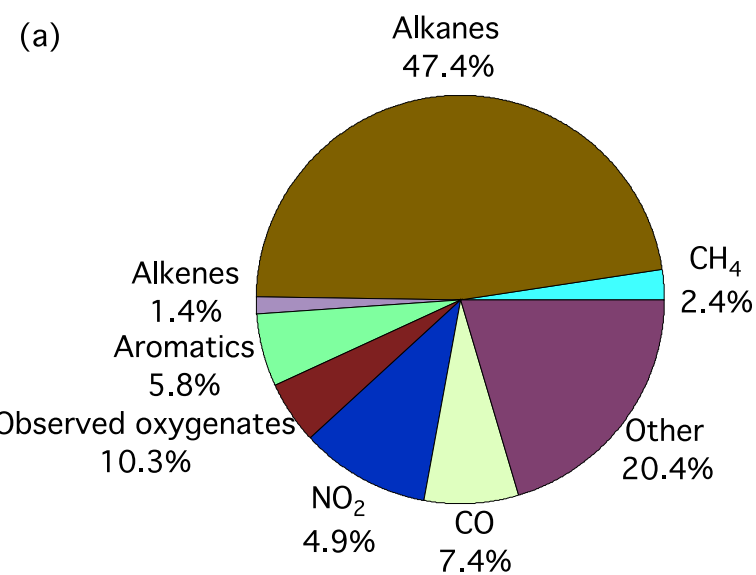

(b)

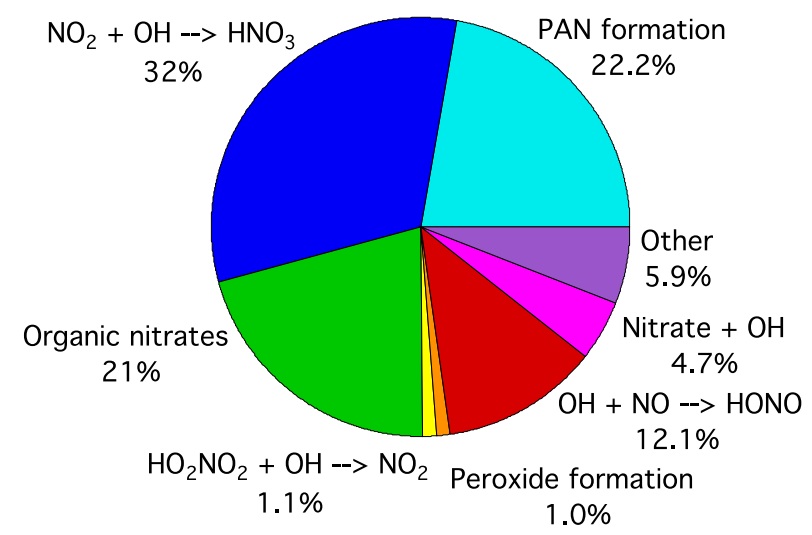

Fig. 11. Pie charts showing relative contributions to $\mathrm{OH}-$ loss reactions (a), and true radical termination reactions (see text for details) (b) within the constrained model simulation.

complete set of oxidation products, and even a twofold uncertainty in this calculation would not significantly alter the conclusion that $\mathrm{OH}$ reactivity is dominated by VOCs rather than $\mathrm{NO}_{\mathrm{x}}$. However, the $\mathrm{OH}+\mathrm{VOC}$ reactions in Fig. 11a are not radical termination reactions, but rather radical propagation steps through the formation of peroxy radicals. Figure $11 \mathrm{~b}$ shows that the total radical $\left(\Sigma\left(\mathrm{OH}+\mathrm{Cl}+\mathrm{HO}_{2}+\right.\right.$ $\left.\mathrm{RO}_{2}+\mathrm{RO}\right)$ ) termination processes are dominated (>95\%) by reactions with nitrogen compounds. This figure includes the reaction of $\mathrm{OH}$ with $\mathrm{NO}$ as a radical loss even though, as described in Sect. 4, much of the HONO produced undergoes photolysis and thus can also be considered a radical reservoir. However, as many of the other species produced during the radical termination reactions shown in Fig. $11 \mathrm{~b}$ can undergo photolysis (e.g., $\mathrm{HNO}_{3}$ ) or thermal dissociation (e.g., PAN) to various extents, it was decided to view all reactions where radicals are lost, but not re-formed, as radical terminations, with the exception of $\mathrm{HO}_{2} \mathrm{NO}_{2}$ and $\mathrm{CH}_{3} \mathrm{O}_{2} \mathrm{NO}_{2}$ formation. These two exceptions were made as the rapid cycling of $\mathrm{HO}_{2}$ and $\mathrm{CH}_{3} \mathrm{O}_{2}$ through $\mathrm{HO}_{2} \mathrm{NO}_{2}$ and $\mathrm{CH}_{3} \mathrm{O}_{2} \mathrm{NO}_{2}$, respectively, would otherwise dominate the calculated radical termination reactions. The short lifetimes of $\mathrm{HO}_{2} \mathrm{NO}_{2}(\sim 6$ min) and $\mathrm{CH}_{3} \mathrm{O}_{2} \mathrm{NO}_{2}(\sim 10 \mathrm{~s})$, compared with HONO (18 min at solar noon and $\sim 1$ day at night for HONO), mean they are true reservoir species and not termination reactions. The overwhelming loss of radicals via nitric/nitrate/PAN formation is indicative of the low radical concentrations within the model, resulting in radical-radical reactions being insignificant.

The low radical production rates and $\mathrm{NO}_{\mathrm{x}}$ dominance of the radical termination reactions in the constrained base model simulation indicate a highly radical limited environment with respect to $\mathrm{O}_{3}$ production. It is, however, more conventional when considering $\mathrm{O}_{3}$ mitigation strategies to consider $\mathrm{O}_{3}$ photochemistry in terms of VOC or $\mathrm{NO}_{\mathrm{x}}$ sensitivity. The approach of Kleinman (1994) describes $\mathrm{NO}_{\mathrm{x}}$ limited and VOC limited regimes in terms of a balance between radical production rate $\left(P_{\text {radical }}\right)$ and $\mathrm{NO}_{\mathrm{x}}$ emission rate $\left(E_{\mathrm{NO}_{\mathrm{x}}}\right)$. Systems that are VOC and $\mathrm{NO}_{\mathrm{x}}$ limited are then defined as follows:

$\mathrm{NO}_{\mathrm{x}}$ limited : $P_{\text {radical }}>E_{\mathrm{NO}_{\mathrm{x}}}$

VOC limited : $P_{\text {radical }}<E_{\mathrm{NO}_{\mathrm{x}}}$

When the production of radicals is greater than the emission of $\mathrm{NO}_{\mathrm{x}}$, the major loss of total radicals is through reaction with VOCs and the system is sensitive to the $\mathrm{NO}_{\mathrm{x}}$ concentration, as these species primarily act to increases the $\mathrm{OH}$ chain length. When $\mathrm{NO}_{\mathrm{x}}$ emission is larger than the radical production rate, the major loss of radicals is reaction with $\mathrm{NO}_{\mathrm{x}}$, and the system is sensitive to the VOC concentration, due to the competition of VOCs for the available radicals.

This balance between radical production and $\mathrm{NO}_{\mathrm{x}}$ emission can be described by the ratio of the total rate of radical removal by reactions with $\mathrm{NO}_{\mathrm{x}}\left(L_{\mathrm{N}}\right)$ to the total rate of radical production $\left(P_{\text {radical }}\right)($ Eq. 1) (Kleinman, 2005). If the majority of radical termination steps proceed via reactions with $\mathrm{NO}_{\mathrm{x}}$ then $L_{\mathrm{N}} / P_{\text {radical }}>0.5$, and the system is VOC sensitive. If radical-radical interactions are the dominant mechanism for radical chain termination then $L_{\mathrm{N}} / P_{\text {radical }}<0.5$ and the system is $\mathrm{NO}_{\mathrm{x}}$ sensitive.

$L_{\mathrm{N}} / P_{\text {radical }}=\frac{\text { Rate of radical removal by } \mathrm{NO}_{\mathrm{x}}}{\text { Rate of radical production }}$

Figure 12 shows that the calculated $L_{\mathrm{N}} / P_{\text {radical }}$ ratio for the constrained model simulation is consistently greater than 0.9 , indicating that the $\mathrm{O}_{3}$ production is in a highly VOC limited regime. This result initially seems counterintuitive, due to the large VOC and relatively modest $\mathrm{NO}_{\mathrm{x}}$ concentrations observed during UBWOS $2012\left(\mathrm{VOC}(\mathrm{ppbC}) / \mathrm{NO}_{\mathrm{x}}(\mathrm{ppb})=\right.$ 347 ), but can be explained due to the very low radical production rates (e.g., $\mathrm{OH}$ production from ozone photolysis is approximately 60 times smaller than a typical summertime regime, see above) resulting in the majority of radical termination reactions being with $\mathrm{NO}_{\mathrm{x}}$. The chemical system under 


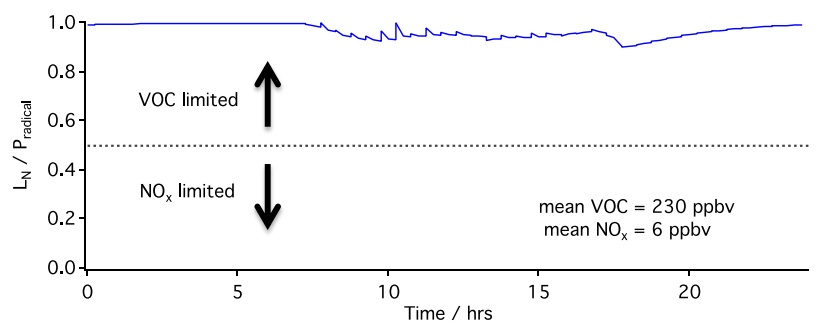

Fig. 12. Calculated $L_{\mathrm{N}} / P_{\text {radical }}$ ratio for the constrained model day.

these conditions is highly sensitive to any change in VOC concentration, as the VOCs compete with $\mathrm{NO}_{\mathrm{x}}$ for the available radicals.

Changing the VOC and $\mathrm{NO}_{\mathrm{x}}$ concentrations within the model confirms that the $\mathrm{O}_{3}$ production chemistry during UBWOS 2012, as modeled here, is VOC limited. Figure 13 shows (a) the calculated $\mathrm{O}_{3}$ mixing ratio and (b) $\mathrm{O}_{3}$ production rate for simulations where the mixing ratios of all the observed VOCs and the $\mathrm{NO}_{\mathrm{x}}$ emission are independently increased and decreased by a factor of 2 . Increasing the VOC mixing ratio by a factor of 2 results in an increase in steady state daily peak $\mathrm{O}_{3}$ of $48 \%$, from $33.1 \mathrm{ppbv}$ to $49.1 \mathrm{ppbv}$, and an increase in the daily ozone production rate (offset to zero at sunrise) from $15.2{\mathrm{ppbv} d a y^{-1}}^{-10} 20.8 \mathrm{ppbv}_{\text {day }}{ }^{-1}$. Conversely, a decrease in the VOC mixing ratio by a factor of 2 results in a $36 \%$ decrease in peak $\mathrm{O}_{3}$ mixing ratio, to $21.1 \mathrm{ppbv}$, and a decrease in daily ozone production rate to 11.2 ppbv day ${ }^{-1}$. In contrast, increasing the $\mathrm{NO}_{\mathrm{x}}$ emission by a factor of 2 results in a decrease in the calculated peak $\mathrm{O}_{3}$ mixing ratio of $65 \%$, to $11.6 \mathrm{ppbv}$, and a reduction in the ozone production rate to $1.6 \mathrm{ppbv}$ day $^{-1}$. This large decrease in ozone production is due to the increased $\mathrm{O}_{3}$ destruction through titration by $\mathrm{NO}$, due to lower radical concentrations resulting in fewer $\mathrm{NO}$ to $\mathrm{NO}_{2}$ conversions and thus much higher $\mathrm{NO}$ mixing ratios. Reducing the $\mathrm{NO}_{\mathrm{x}}$ emission by a factor of 2 results in an increase in peak $\mathrm{O}_{3}$ mixing ratio to $48.6 \mathrm{ppbv}$ and an increase in $\mathrm{O}_{3}$ production rate to 17.8 ppbv day $^{-1}$. Although the steady state peak $\mathrm{O}_{3}$ mixing ratio increases to a similar value in the reduced $\mathrm{NO}_{\mathrm{x}}$ simulation as in the increased VOC simulation, the lower $\mathrm{O}_{3}$ production rate indicates that this is partially due to a reduction in the losses of $\mathrm{O}_{3}$ and that the system is still in a VOC limited regime.

The box model calculations described in the sections above show that the $\mathrm{O}_{3}$ photochemistry in the wintertime Uintah Basin during UBWOS 2012 was highly radical limited. The low radical production rate results in few radicalradical interactions, resulting in radical termination proceeding almost exclusively through reactions with $\mathrm{NO}_{\mathrm{x}}$. The $\mathrm{NO}_{\mathrm{x}}$ domination of the radical chain termination reactions in turn means that, despite the unusually high VOC mixing ratios observed, $\mathrm{O}_{3}$ production in this environment is in a VOC limited regime. This conclusion is similar to three of
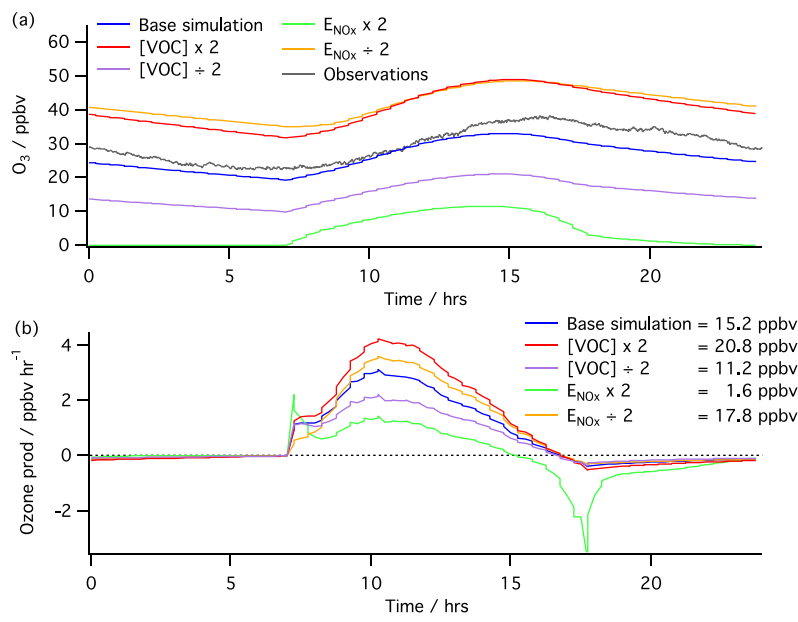

Fig. 13. (a) $\mathrm{O}_{3}$ and (b) $\mathrm{P}\left(\mathrm{O}_{3}\right)$ response to increasing and decreasing the $[\mathrm{VOC}]$ and $\mathrm{NO}_{\mathrm{x}}$ emission rate by a factor of 2 .

the four case studies of individual wintertime $\mathrm{O}_{3}$ events in Wyoming's Upper Green River basin reported by Carter and Seinfeld (2012). Despite a significantly different $\mathrm{NO}_{\mathrm{x}} / \mathrm{VOC}$ mixture and VOC speciation observed in the Wyoming study compared to this work, a set of model sensitivity studies found three of the four events modeled to be in a VOC limited regime. Note that the simulation of UBWOS 2012 is not for high $\mathrm{O}_{3}$ events and not for cold-pool conditions, as in the Wyoming events. Nevertheless, both wintertime simulations show VOC, rather than $\mathrm{NO}_{x}$, limitation of $\mathrm{O}_{3}$ photochemistry. In the absence of strong $\mathrm{O}_{3}$ production during UBWOS 2012 , the sources of the different radical precursor species during a cold-pool event are uncertain. The simulations in this section do not address the influence of $\mathrm{NO}_{\mathrm{x}}$ concentration on the production rates of $\mathrm{HONO}$ and $\mathrm{ClNO}_{2}$, which are produced via $\mathrm{NO}_{\mathrm{x}}$ chemistry. It is likely that an increase in $\mathrm{NO}_{\mathrm{x}}$ emission would result in an increase in the production of these radical precursor species, which in turn would increase $\mathrm{O}_{3}$ production in this radical limited environment. Observations of these radical precursor species under coldpool, strong $\mathrm{O}_{3}$ production conditions are required to confirm the chemical sensitivities described in this section. Observations of $\mathrm{OH}$ and $\mathrm{HO}_{2}$ radical concentrations, as well as $\mathrm{OH}$ reactivity, would also be beneficial during a wintertime $\mathrm{O}_{3}$ pollution event, as these measurements would provide an excellent test of the models skill in representing the radical sources and sinks.

\section{Simulation of cold-pool event}

Box model analysis of the UBWOS 2012 data set has provided a good understanding of the photochemistry controlling $\mathrm{O}_{3}$ production during the conditions observed during the 2012 wintertime, when there was no snow or cold-pool conditions, and no $\mathrm{O}_{3}$ measurements above the NAAQS. Based 

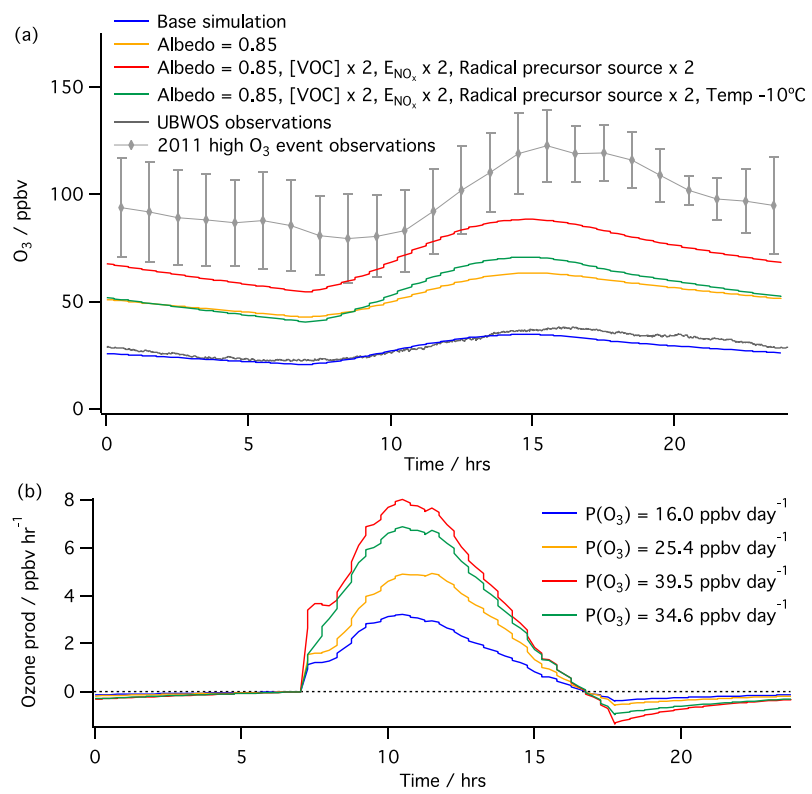

Fig. 14. Calculated $\mathrm{O}_{3}(\mathbf{a})$ and $\mathrm{P}\left(\mathrm{O}_{3}\right)$ (b) response to simulations of conditions expected during a cold-pool event.

on the success in reproducing this photochemistry, we can use the same model to simulate the conditions expected for a cold-pool event, similar to the winters of 2009-2010 and 2010-2011. Wintertime $\mathrm{O}_{3}$ pollution events coincide with periods of stable high-pressure weather systems and surface snow cover. These conditions result in shallow temperature inversions, confining surface emissions to a stagnant boundary layer of often less than 100m (Schnell et al., 2009; Martin et al., 2011). As the cold-pool conditions are characterized by a relatively constant boundary layer height throughout a diurnal cycle, the chemistry is ideally suited to simulating using a box model. Although observational constraints relating to chemical processes unique to these conditions are lacking, such as snowpack photochemistry (Grannas et al., 2007), we attempt to simulate the physical changes in the system. A shallow stagnant boundary layer confines surface emissions to a smaller volume than was observed during UBWOS 2012, thus increasing the concentrations of $\mathrm{O}_{3}$ precursor species. Snow cover increases the albedo of the ground surface, which leads to increased photolysis rates. Both of these physical changes have been represented in the box model, and their impact on calculated $\mathrm{O}_{3}$ production assessed.

In the base simulation (i.e., without increased albedo due to snow cover), the concentrations of the radical precursor species $\mathrm{HONO}, \mathrm{HCHO}$ and $\mathrm{ClNO}_{2}$ were constrained to their average diurnal concentration profiles observed during UBWOS 2012. Increasing the photolysis within the model, due to a changing surface albedo, whilst maintaining these observed precursor concentrations, however, would cause an overestimation of the radical source strength from the photolysis of these species. For simulation of cold-pool con- ditions, the concentrations of these radical precursors have been constrained using an emission rate, instead of constraining the concentrations themselves. These emissions represent the missing sources of $\mathrm{HONO}$ and $\mathrm{HCHO}$ that are not present in the chemistry scheme, and the entire source of $\mathrm{ClNO}_{2}$. Changing the base simulation from constraining to the observed radical precursor concentrations to an emission results in an increase of approximately $5 \%$ in both the calculated peak $\mathrm{O}_{3}$ mixing ratio, $33.1 \mathrm{ppbv}$ and $34.8 \mathrm{ppbv}$, and the normalized daily $\mathrm{O}_{3}$ production rate, 15.2 to $16.0 \mathrm{ppbv}$ day $^{-1}$.

Figure 14 shows (a) the calculated $\mathrm{O}_{3}$ mixing ratio profiles and (b) calculated $\mathrm{O}_{3}$ production rates for three simulations of different cold-pool conditions relative to the constrained UBWOS 2012 case. Figure 14a also shows the average diurnal $\mathrm{O}_{3}$ mixing ratios observed during UBWOS 2012 and those observed at the Horse Pool site during the elevated $\mathrm{O}_{3}$ event between 12-16 February 2011 (see Fig. 2). The simulation shown in yellow has the same VOC concentrations and $\mathrm{NO}_{\mathrm{x}}$ and radical precursor emissions as the base model, but with the surface albedo increased from 0.1 to 0.85 to simulate a snow-covered surface. This increase in photolysis results in increases of the daily peak $\mathrm{HO}_{2}$ and $\mathrm{OH}$ concentrations of $100 \%$ and $70 \%$, respectively, due to increases in radical production from photolysis. The higher radical concentration increase the $\mathrm{O}_{3}$ production rate from $16.0 \mathrm{ppb}$ day $^{-1}$ to $25.4 \mathrm{ppbv} d a y^{-1}$, and thus the calculated daily peak $\mathrm{O}_{3}$ mixing ratio increases from $34.8 \mathrm{ppbv}$ to $63.4 \mathrm{ppbv}$.

To simulate a reduced boundary layer the model calculation shown in red in Fig. 14 has all VOC concentrations, and the $\mathrm{NO}_{\mathrm{x}}$ and radical precursor emissions increased by a factor of 2, as well as a surface albedo of 0.85 . In contrast to the simulations in the previous section, emissions of the radical precursor species $\mathrm{HCHO}, \mathrm{HONO}$, and $\mathrm{ClNO}_{2}$ have been increased in these cold-pool simulations. These radical precursor emissions represent the fraction of the required source that cannot be explained by the chemistry scheme and therefore likely originate from either a primary emission or a chemical reaction of species emitted within the basin. It is probable that concentrations of emitted species could increase by more than a factor of 2 during cold-pool events, with boundary layer heights decreasing to $<100 \mathrm{~m}$. A factor of 2 was chosen to test the sensitivity of the system, since there is a lack of observational constraints and uncertainties remain about how the sources of $\mathrm{HONO}, \mathrm{HCHO}$ and $\mathrm{ClNO}_{2}$ would be impacted. The increase in $\mathrm{O}_{3}$ precursor concentrations along with the surface albedo change gives a daily $\mathrm{O}_{3}$ production rate of 39.5 ppbv day ${ }^{-1}$, and a peak daily $\mathrm{O}_{3}$ mixing ratio of 88.4 ppbv. This calculated $\mathrm{O}_{3}$ mixing ratio is considerably lower than, but at least approaches that observed during the most intense $\mathrm{O}_{3}$ pollution event at Horse Pool in 2011.

The final simulation shown in Fig. 14 (green), tests the sensitivity of $\mathrm{O}_{3}$ production to reduced temperatures during a cold-pool event. For this calculation VOC concentrations and emissions of $\mathrm{NO}_{\mathrm{x}}$ and radical precursors were kept at 
twice that used in the constrained UBWOS 2012 base simulation, along with a surface albedo of 0.85 , but the temperature in the model was reduced by $10^{\circ} \mathrm{C}$, giving an average temperature of $-10.4^{\circ} \mathrm{C}$. This temperature is typical of those observed during previous cold-pool events (Martin et al., 2011). As the kinetics of many of the $\mathrm{OH}+\mathrm{VOC}$ reactions show a significant temperature dependence, the overall amount of oxidation decreases in this "cold" simulation. This results in a reduction in radical concentrations, $-12 \%$ for $\mathrm{OH}$ and $-43 \%$ for $\mathrm{HO}_{2}$, largely due to a reduction in the photochemical production of the dominant radical source $\mathrm{HCHO}$. The decrease in radical concentrations also reduces the loss of $\mathrm{NO}_{\mathrm{x}}$ species, largely through a decrease in $\mathrm{HNO}_{3}$ formation, giving an increase in the total $\mathrm{NO}_{\mathrm{x}}$ concentration in the model. A reduction in $\mathrm{NO}$ to $\mathrm{NO}_{2}$ conversions via reactions with peroxy radicals also results in a higher $\mathrm{NO}: \mathrm{NO}_{2}$ ratio than in the warmer simulation, giving increased $\mathrm{O}_{3}$ loss through reaction with NO. The overall impact of a $10^{\circ} \mathrm{C}$ reduction in temperature on daily $\mathrm{O}_{3}$ production rate is a reduction from $39.5{\mathrm{ppbv} d a y^{-1}}^{-10} 34.6 \mathrm{ppbv}^{-1} \mathrm{day}^{-1}$, resulting in a daily peak $\mathrm{O}_{3}$ mixing ratio reduction of $17.6 \mathrm{ppbv}$ to $70.8 \mathrm{ppbv}$.

The model simulations of a cold-pool event in this section indicate that $\mathrm{O}_{3}$ production is enhanced, but is still significantly lower than that observed during previous $\mathrm{O}_{3}$ pollution events (e.g., Fig. 2). Recent observations, however, may indicate that the factor of 2 increases in $\mathrm{O}_{3}$ precursor emissions chosen to represent a compressed boundary layer is insufficient. The behavior of radical sources that arise from heterogeneous reactions of nitrogen oxides, such as HONO and $\mathrm{ClNO}_{2}$, is also difficult to predict for the cold-pool conditions, and represents a significant uncertainty in these simulations. To test these model conclusions, observations during an $\mathrm{O}_{3}$ pollution episode are required to provide information on how radical sources change and how the cold-pool conditions and snow cover impact other parameters, such as $\mathrm{O}_{3}$ deposition rates.

\section{Conclusions}

Simulations of ozone observations during UBWOS 2012 in Utah's Uintah Basin, a major oil and natural gas producing region, have provided insight into the mechanisms for ozone production in a polluted winter environment. The motivation for the campaign was the occurrence of high $\mathrm{O}_{3}$ events during the winters of 2009-2010 and 2010-2011, which were characterized by cold-pool conditions in the Uintah basin, with snow on the ground. The 2012 study did not have snow cover, a cold-pool event, nor $\mathrm{O}_{3}$ in excess of national ambient air quality standards. Nevertheless, the detailed measurements that took place during six weeks of sampling (15 January-1 March 2012) have provided unprecedented detail of the chemical composition of the air masses in this region.
Despite the lack of cold-pool conditions, there was a regular diurnal cycle of surface ozone with partial nighttime titration by $\mathrm{NO}_{\mathrm{x}}$ emissions and daytime chemical production. The simulations with an explicit VOC degradation scheme accurately simulated the observed daily ozone production. A key finding from this simulation was the low $\mathrm{OH}$ production from $\mathrm{O}\left({ }^{1} \mathrm{D}\right)+\mathrm{H}_{2} \mathrm{O}$, accounting for only $170 \mathrm{pptv}^{\mathrm{day}}{ }^{-1}$ of primary radical production and only $7.6 \%$ of primary radicals. Other primary radical sources that were important included the photolysis of HCHO (52.3\%), HONO (25.8\%) and $\mathrm{ClNO}_{2}(12.8 \%)$, as well as $\mathrm{OH}$ from the reaction of $\mathrm{O}_{3}$ with alkenes $(1.5 \%)$. Even though it is produced as a secondary product in the degradation of VOCs, formaldehyde photolysis was considered a primary radical source for this analysis because the simulations could not reproduce the observed $\mathrm{HCHO}$, and because its production represents a radical amplification step. Radical amplification reactions during the oxidation of the observed aromatic VOCs were also identified as a significant radical source, making these species 30-40 times more effective $\mathrm{O}_{3}$ producers than the same concentrations of other, non-aromatic, VOCs in this environment. Radical production was low enough to be small in comparison to the emissions of nitrogen oxides, such that $\mathrm{NO}_{\mathrm{x}}$ acted as the primary radical sink. This low primary radical production makes the system highly radical limited. The consequence was that the system was highly VOC sensitive despite the much larger mixing ratio of total non-methane hydrocarbons (230 ppbv, 6 week average) relative to $\mathrm{NO}_{\mathrm{x}}$ (5.6 ppbv average). Simulations with halved or doubled concentrations of VOCs and $\mathrm{NO}_{\mathrm{x}}$ confirmed the sensitivity to VOCs, with a $48 \% \mathrm{O}_{3}$ increase for a doubling of VOCs and a $65 \%$ decrease in $\mathrm{O}_{3}$ for a doubling of $\mathrm{NO}_{\mathrm{x}}$. These simulations do not, however, include the impact of changing $\mathrm{NO}_{\mathrm{x}}$ concentrations on radical precursor concentrations, which would likely increase with increasing $\mathrm{NO}_{\mathrm{x}}$ and thus increase $\mathrm{O}_{3}$ production.

Extrapolation of these results to a cold-pool event with snow on the ground is difficult, since the importance of each radical source under these conditions is unknown, and the concentration increase associated with the reduced boundary layer height is uncertain. Simulations with factor of two increases in VOC concentrations and emissions of $\mathrm{NO}_{\mathrm{x}}$ and the radical precursors $\mathrm{HCHO}, \mathrm{HONO}$, and $\mathrm{ClNO}_{2}$ (designed to simulate lower boundary layer heights) together with surface albedo increased from 0.1 to 0.85 to represent the snow surface and a temperature decreased by $10^{\circ} \mathrm{C}$, are significantly closer to the observations of a five-day peak $\mathrm{O}_{3}$ period from the winter of 2010-2011, but still fall substantially short of reproducing the highest observed concentrations. Future detailed measurements during cold-pool conditions, particularly those that characterize the sources of primary radicals and the increases in VOCs, $\mathrm{NO}_{\mathrm{x}}$ and surface albedo, will be critical to understanding the phenomenon of severe $\mathrm{O}_{3}$ events during winter in oil and gas producing regions. 


\section{Supplementary material related to this article is available online at http://www.atmos-chem-phys.net/13/ 8955/2013/acp-13-8955-2013-supplement.pdf.}

Acknowledgements. This work was supported in part by the Western Energy Alliance, and NOAA's Climate and Health of the Atmosphere programs. We thank Questar Energy Products for site preparation and support. Robert McLaren acknowledges receipt of a York University Sabbatical Leave Fellowship, which partially funded his participation in the study. Joel Thornton acknowledges NSF-AGS CAREER Grant No. 0846183.

The scientific results and conclusions, as well as any views or opinions expressed herein, are those of the author(s) and do not necessarily reflect the views of NOAA or the Department of Commerce.

Edited by: J. Liggio

\section{References}

Andersson-Skold, Y., Grennfelt, P. and Pleijel, K.: Photochemical Ozone Creation Potentials: A Study of Different Concepts, J. Air Waste Manage. Assoc., 42, 1152-1158, 1992.

Altshuller, A. P.; Production of aldehydes as primary emissions and from secondary atmospheric reactions of alkenes and alkanes during the night and early morning hours, Atmos. Environ., 27, 21-32, 1993.

Ammar, R., Monge, M. E., George, C., and D'Anne, B.: Photoenhanced $\mathrm{NO}_{2}$ Loss on Simulated Urban Grime, Chem. Phys. Chem., 11, 3956-3961, 2010.

Atkinson, R., Baulch, D. L., Cox, R. A., Crowley, J. N., Hampson, R. F., Hynes, R. G., Jenkin, M. E., Rossi, M. J., Troe, J., and IUPAC Subcommittee: Evaluated kinetic and photochemical data for atmospheric chemistry: Volume II - gas phase reactions of organic species, Atmos. Chem. Phys., 6, 3625-4055, doi:10.5194/acp-6-3625-2006, 2006.

Atkinson, R., Baulch, D. L., Cox, R. A., Crowley, J. N., Hampson, R. F., Hynes, R. G., Jenkin, M. E., Rossi, M. J., and Troe, J.: Evaluated kinetic and photochemical data for atmospheric chemistry: Volume III - gas phase reactions of inorganic halogens, Atmos. Chem. Phys., 7, 981-1191, doi:10.5194/acp-7-981-2007, 2007.

Bohn, B. and Zetzsch, C.: Kinetics and mechanism of the reaction of $\mathrm{OH}$ with the trimethylbenzenes - experimental evidence for the formation of adduct isomers, Phys. Chem. Chem. Phys, 14, 13933-13948, 2012.

Brown, J. S., Bateson, T. F. and McDonnell F.: Effects of exposure to 0.06 ppm ozone on FEV1 in humans: A secondary analysis of existing data, Environ. Health Perspect., 116, 1023-1026, 2008.

Carter, W. P. L. and Seinfeld, J. H.: Winter ozone formation and VOC incremental reactivities in the Upper Green River Basin of Wyoming, Atmos. Environ., 50, 255-266, 2012.

Crutzen, P. J.: Global tropospheric chemistry, in: Low-Temperature Chemistry of the Atmosphere, edited by: Moortgat, G. K., Barnes, A. J., Le Bras, G., and Sodeau, J. R., NATO ASI Ser., Vol. 121, 465-498, Springer, New York, 1994.
Derwent, R. G., Jenkin, M. E., and Saunders, S. M.: Photochemical ozone creation potentials for a large number of reactive hydrocarbons under European conditions, Atmos. Environ., 30, 181-199, 1996.

Derwent, R. G., Jenkin, M. E., Saunders, S. M., and Pilling, M. J.: Photochemical ozone creation potentials for organic compounds in northwest Europe calculated with a Master Chemical Mechanism, Atmos. Environ., 32, 2429-2441, 1998.

Edwards, P. E., Evans, M. J., Commane, R., Ingham, T., Stone, D., Mahajan, M. S., Oetjen, H., Dorsey, J. R., Hopkins, J. R., Lee, J. D., Moller, S. J., Leigh, R., Plane, J. M. C., Carpenter, L. J., and Heard, D. E.: Hydrogen oxide photochemistry in the northern Canadian spring time boundary layer, J. Geophys. Res., 116, D22306, doi:10.1029/2011JD016390, 2012.

Emmerson, K. M. and Evans, M. J.: Comparison of tropospheric gas-phase chemistry schemes for use within global models, Atmos. Chem. Phys., 9, 1831-1845, doi:10.5194/acp-9-1831-2009, 2009.

Environmental Protection Agency, (EPA), Air quality criteria for ozone and other photochemical oxidants, EPA/600/8-84-020CF and EPA/600/8-84-020-EF, U.S. Environ. Prot. Agency, Research Triangle Park, NC, 1986.

EIA: US Energy Information Administration, Annual Energy Outlook 2013, available at: www.eia.gov, 2013.

Fantechi, G., Jensen, N. R., Saastad, O., Hjorth, J., and Peeters, J.: Reactions of $\mathrm{Cl}$ atoms with selected VOCs: kinetics, products and mechanisms, J. Atmos. Chem., 31, 247-267, 1998.

Finlayson-Pitts, B. J. and Pitts, J. N.: Tropospheric Air Pollution: Ozone, Airborne Toxics, Polycyclic Aromatic Hydrocarbons and Particles, Science, 276, 1045-1052, 1997.

Finlayson-Pitts, B. J., Wingen, L. M., Sumner, A. L., Syomin, D., and Ramazan, K. A.: The heterogeneous hydrolysis of $\mathrm{NO}_{2}$ in laboratory systems and in outdoor and indoor atmospheres: An integrated mechanism, Phys. Chem. Chem. Phys., 5, 223-242, 2003.

Fried, A., Crawford, J., Olson, J., Walega, J., Potter, W., Wert, B., Jordan, C., Anderson, B., Shetter, R., Lefer, B., Blake, D., Blake, N., Meinardi, S., Heikes, B., O’Sullivan, D., Snow, J., Fuelberg, H., Kiley, C. M., Sandholm, S., Tan, D., Sachse, G., Singh, H., Faloona, I., Harward, C. N., and Carmichael, G. R.: Airborne tunable diode laser measurements of formaldehyde during TRACEP: Distributions and box model comparisons, J. Geophys. Res., 108, 8798, doi:10.1029/2003JD003451, 2003.

Frost, G. J., Fried, A., Lee, Y. N., Wert, B., Henry, B., Drummond, J. R., Evans, M. J., Fehsenfeld, F. C., Goldan, P. D., Holloway, J. S., Hubler, G., Jakoubek, R., Jobson, B. T., Knapp, K., Kuster, W. C., Roberts, J., Rudolph, J., Ryerson, T. B., Stohl, A., Stroud, C., Sueper, D. T., Trainer, M., and Williams, J.: Comparisons of box model calculations and measurements of formaldehyde from the 1997 North Atlantic Regional Experiment, J. Geophys. Res., 107, 4060, doi:10.1029/2001JD000896, 2002.

Ghosh, B., Papanastasiou, D. K., Talukdar, R. K., Roberts, J. M. and Burkholder, J. B.: Nitryl Chloride $\left(\mathrm{ClNO}_{2}\right)$ : UV/Vis Absorption Spectrum between 210 and $296 \mathrm{~K}$ and $\mathrm{O}\left({ }^{3} \mathrm{P}\right)$ Quantum Yield at 193 and $248 \mathrm{~nm}$, J. Phys. Chem. A., 116, 5796-5805, 2012.

Gillman, J. B., Lerner, B. M., Kuster, W. C., and de Gouw, J. A.: Source Signature of Volatile Organic Compounds from Oil and Natural Gas Operations in Northeastern Colorado, Environ. Sci. Technol., 47, 1297-1305, 2013. 
Grannas, A. M., Jones, A. E., Dibb, J., Ammann, M., Anastasio, C., Beine, H. J., Bergin, M., Bottenheim, J., Boxe, C. S., Carver, G., Chen, G., Crawford, J. H., Dominé, F., Frey, M. M., Guzmán, M. I., Heard, D. E., Helmig, D., Hoffmann, M. R., Honrath, R. E., Huey, L. G., Hutterli, M., Jacobi, H. W., Klán, P., Lefer, B., McConnell, J., Plane, J., Sander, R., Savarino, J., Shepson, P. B., Simpson, W. R., Sodeau, J. R., von Glasow, R., Weller, R., Wolff, E. W., and Zhu, T.: An overview of snow photochemistry: evidence, mechanisms and impacts, Atmos. Chem. Phys., 7, 43294373, doi:10.5194/acp-7-4329-2007, 2007.

Hough, A. M. and Derwent, R. G.: Computer modelling studies of the distribution of photochemical ozone production between different hydrocarbons, Atmos. Environ., 21, 2015-2033, 1987.

Jenkin, M. E., Saunders, S. M., and Pilling, M. J.: The tropospheric degradation of volatile organic compounds: A protocol for mechanism development, Atmos. Environ., 31, 81-104, 1997.

Jenkin, M. E., Saunders, S. M., Wagner, V., and Pilling, M. J.: Protocol for the development of the Master Chemical Mechanism, MCM v3 (Part B): tropospheric degradation of aromatic volatile organic compounds, Atmos. Chem. Phys., 3, 181-193, doi:10.5194/acp-3-181-2003, 2003.

Jerrett, M., Burnett, R. T., Pope, C. A., Ito, K., Thurston, G., Krewski, D., Shi, Y. L., Calle, E., and Thun, M.: LongTerm Ozone Exposure and Mortality, New England Journal of Medicine, 360, 1085-1095, doi:10.1056/NEJMoa0803894, 2009.

Jiang, W., Singleton, D. L., McLaren, R., and Hedley, M.: Sensitivity of ozone concentrations to rate constants in a modified SAPRC90 chemical mechanism used for Canadian Lower Fraser Valley ozone studies, Atmos. Environ., 31, 1195-1208, 1997.

Jones, N. B., Riedel, K., Allan, W., Wood, S., Palmer, P. I., Chance, K., and Notholt, J.: Long-term tropospheric formaldehyde concentrations deduced from ground-based fourier transform solar infrared measurements, Atmos. Chem. Phys., 9, 7131-7142, doi:10.5194/acp-9-7131-2009, 2009.

Katzenstein, A. S., Doezema, L. A., Simpson, I. J., Blake, D. R., and Rowland, F. S.: Extensive regional atmospheric hydrocarbon pollution in the southwestern United States, P. Natl. Acad. Sci., 100, 11975-11979, doi:10.1073/pnas.1635258100, 2003.

Kleinman, L. I.: Low- and high-NOx tropospheric photochemistry, J. Geophys. Res., 99, 16831-16838, 1994.

Kleinman, L. I.: The dependence of tropospheric ozone production rate on ozone precursors, Atmos. Envirom., 39, 575-586, 2005.

Koch, R., Knispel, R., Elend, M., Siese, M., and Zetzsch, C.: Consecutive reactions of aromatic-OH adducts with $\mathrm{NO}, \mathrm{NO}_{2}$ and $\mathrm{O}_{2}$ : benzene, naphthalene, toluene, $\mathrm{m}$ - and p-xylene, hexamethylbenzene, phenol, m-cresol and aniline, Atmos. Chem. Phys., 7, 2057-2071, doi:10.5194/acp-7-2057-2007, 2007.

Levy, H.: Photochemistry of the lower troposphere, Planet Space Sci., 20, 919-935, 1972.

Loison, J., Rayez, M., Rayez, J., Gratien, A., Morajkar, P., Fittschen, C., and Villenave, E.: Gas-Phase Reactuion of Hydroxyl Radical with Hexamethylbenzene, J. Phys. Chem, A., 116, 12189-12197, 2012.

Lowe, D. and Schmidt, U.: Formaldehyde (HCHO) measurements in the nonurban atmosphere, J. Geophys. Res., 88, 10844-10858, 1983.

Madronich, S. and Flocke, S.: The role of solar radiation in atmospheric chemistry, in: Handbook of environmental chemistry, edited by: Boule, P., Springer Verlag, Heidelberg, 1-26, 1998.

Martin, R., Moore, K., Mansfield, M., Hill, S., Harper, K., and Shorthill, H.: Final Report: Uinta Basin Winter Ozone and Air Quality Study December 2010 - March 2011, Energy Dynamics Laboratory, EDL/11-039, available at: http://rd.usu.edu/files/ uploads/ubos_2010-11_final_report.pdf, 2011.

Monge, M. E., D’Anna, B., Mazri, L., Giroir-Fendler, A., Ammann, M., Donaldson, D. J., and George, C.: Light changes the atmospheric reactivity of soot, P. Natl. Acad. Sci., 107, 6605-6609, 2010.

Olaguer, E. P., Rappenglück, B., Lefer, B., Stutz, J., Dibb, J., Griffin, R., Brune, W. H., Shauck, M., Buhr, M., Jeffries, H., Vizuete, W., and Pinto, J. P.; Deciphering the role of radical precursors during the Second Texas Air Quality Study, J. Air Waste Manag. Assoc., 59, 1258-1277, 2009.

Osthoff, H. D., Roberts, J. M., Ravishankara, A. R.,Williams, E. J., Lerner, B. M., Sommariva, R., Bates, T. S., Coffman D., Quinn P. K., Dibb, J. E., Stark, H., Burkholder J. B., Talukdar, R. K., Meagher, J. M., Fehsenfeld, F. C., and Brown, S. S.: High levels of nitryl chloride in the polluted subtropical marine boundary layer, Nat. Geosci., 1, 324-328, 2008.

Petron, G., Frost, G., Miller, B., Hirsch, A. I., Montzka, S. A., Karion, A., Trainer, M., Sweeney, C., Andrews, A. E., Miller, L., Kofler, J., Bar-Ilan, A., Dlugokencky, Ed J., Patrick, L., Moore Jr, C. T., Ryerson, T. B., Siso, C., Kolodzey, W., Lang, P. M., Conway, T., Novelli, P., Masarie, K., Hall, B., Guenther, D., Kitzis, D., Miller, J., Welsh, D., Wolfe, D., Neff, W. and Tans.: Hydrocarbon emissions characterization in the Colorado Front Range - A pilot study, J. Geophys. Res., 107, 4146, doi:10.1029/2011JD016360, 2012.

Riedel, K., Allan, W., Weller, R., and Schrems, O.: Discrepancies between formaldehyde measurements and methane oxidation model predictions in the Antarctic troposphere: An assessment of other possible formaldehyde sources, J. Geophys. Res., 110, D15308, doi:10.1029/2005JD005859, 2005.

Roberts, J. M., Osthoff, H. D., Brown, S. S., Ravishankara, A. R., Coffman, D., Quinn, P., and Bates, T.: Laboratory studies of products of N2O5 uptake on Cl- containing substrates, Geophys. Res. Lett., 36, L20808, doi:10.1029/2009GL040448, 2009.

Roelofs, G.-J. and Lelieveld, J.: Distribution and budget of $\mathrm{O}_{3}$ in the troposphere calculated with a chemistry general circulation model, J. Geophys. Res., 100, 20983-20998, doi:10.1029/95JD02326, 1995.

Sander, S. P., Abbatt, J., Barker, J. R., Burkholder, J. B., Friedl, R. R., Golden, D. M., Huie, R. E., Kolb, C. E., Kurylo, M. J., Moortgat, G. K., Orkin, V. L., and Wine, P. H.: Chemical Kinetics and Photochemical Data for Use in Atmospheric Studies, Evaluation No. 17, JPL Publication 10-6, Jet Propulsion Laboratory, Pasadena, 2011.

Saunders, S. M., Jenkin, M. E., Derwent, R. G., and Pilling, M. J.: Protocol for the development of the Master Chemical Mechanism, MCM v3 (Part A): tropospheric degradation of nonaromatic volatile organic compounds, Atmos. Chem. Phys., 3, 161-180, doi:10.5194/acp-3-161-2003, 2003.

Schnell, R. C., Oltmans, S. J., Neely, R. R., Endres, M. S., Molenar, J. V., and White, A. B.: Rapid photochemical production of ozone at high concentrations in a rural site during winter, Nature Geosci., 2, 120-122, 2009. 
Spivakovsky, C. M., Logan, J. A., Montzka, S. A., Balkanski, Y. J., Foreman-Fowler, M., Jones, D. B. A., Horowitz, L. W., Fusco, A. C., Brenninkmeijer, C. A. M., Prather, M. J., Wolfsy, S. C., and McElroy, M. B.: Three-dimensional climatological distribution of tropospheric $\mathrm{OH}$ : Update and evaluation, J. Geophys. Res., 105, 8931-8980, doi:10.1029/1999JD901006, 2000.

Stemmler, K., Ammann, M., Donders, C., Kleffmann, J., and George, C.: Photosensitized reduction of nitrogen dioxide on humic acid as a source of nitrous acid, Nature, 440, 195-198, 2006.

Stone, D., Evans, M. J., Commane, R., Ingham, T., Floquet, C. F. A., McQuaid, J. B., Brookes, D. M., Monks, P. S., Purvis, R., Hamilton, J. F., Hopkins, J., Lee, J., Lewis, A. C., Stewart, D., Murphy, J. G., Mills, G., Oram, D., Reeves, C. E., and Heard, D. E.: $\mathrm{HO}_{\mathrm{x}}$ observations over West Africa during AMMA: impact of isoprene and $\mathrm{NO}_{\mathrm{x}}$, Atmos. Chem. Phys., 10, 9415-9429, doi:10.5194/acp-10-9415-2010, 2010.

Sumner, A. L. and Shepson, P. B.: Snowpack production of formaldehyde and its effect on the arctic troposphere, Nature, 398, 230-233, 1999.

Thornton, J. A., Wooldridge, P. J., Cohen, R. C., Martinez, M., Harder, H., Brune, W. H., Williams, E. J., Roberts, J. M., Fehsenfeld, F. C., Hall, S. R., Shetter, R. E., Wert, B. P., and Fried, A.: Ozone production rates as a function of $\mathrm{NO}_{\mathrm{X}}$ abundances and $\mathrm{HO}_{\mathrm{x}}$ production rates in the Nashville urban plume, J. Geophys. Res., 107, doi:10.1029/2001JD000932, 2002.
Thornton, J. A., Kercher, J. P., Riedel, T. P.,Wagner, N. L., Cozic, J., Holloway, J. S., Dube, W. P, Wolfe, G. M., Quinn, P. K., Middlebrook, A. M., Alexander, B., and Brown, S. S.: A large atomic chlorine source inferred from mid-continental reactive nitrogen chemistry, Nature, 464, 271-274, 2010.

Tonnesen, G. S. and Dennis, R. L.: Analysis of radical propagation efficiency to assess ozone sensitivity to hydrocarbons and NOx 1. Local indicators of instantaneous odd oxygen production Sensitivity, J. Geophys. Res., 105, 9213-9225, 2000.

Wong, K. W., Oh, H.-J., Lefer, B. L., Rappenglück, B., and Stutz, J.: Vertical profiles of nitrous acid in the nocturnal urban atmosphere of Houston, TX, Atmos. Chem. Phys., 11, 3595-3609, doi:10.5194/acp-11-3595-2011, 2011.

Young, C. J., Washenfelder, R. A., Mielke, L. H., Osthoff, H. D., Veres, P., Cochran, A. K., VandenBoer, T. C., Stark, H., Flynn, J., Grossberg, N., Haman, C. L., Lefer, B., Gilman, J. B., Kuster, W. C., Tsai, C., Pikelnaya, O., Stutz, J., Roberts, J. M., and Brown, S. S.: Vertically resolved measurements of nighttime radical reservoirs in Los Angeles and their contribution to the urban radical budget, Environ. Sci. Technol., 46, 10965-10973, 2012.

Zhou, X., Lee, Y.-N., Newman, L., Chen, X., and Mopper, K.: Tropospheric formaldehyde concentration at Mauna Loa observatory during Mauna Loa Observatory Photochemistry Experiment 2, J. Geophys. Res., 101, 14711-14719, doi:10.1029/95JD03226, 1996. 